US Army Corps

of Engineers ${ }_{\circledast}$

Engineer Research and

Development Center

Aquatic Plant Control Research Program

\title{
Genetic and Morphological Differences of Water Chestnut (Myrtales: Lythraceae: Trapa) Populations in the Northeastern United States, Japan, and South Africa
}

Lynde L. Dodd, Nancy Rybicki, Ryan Thum, Yasuro Kadono,

and Kadiera Ingram

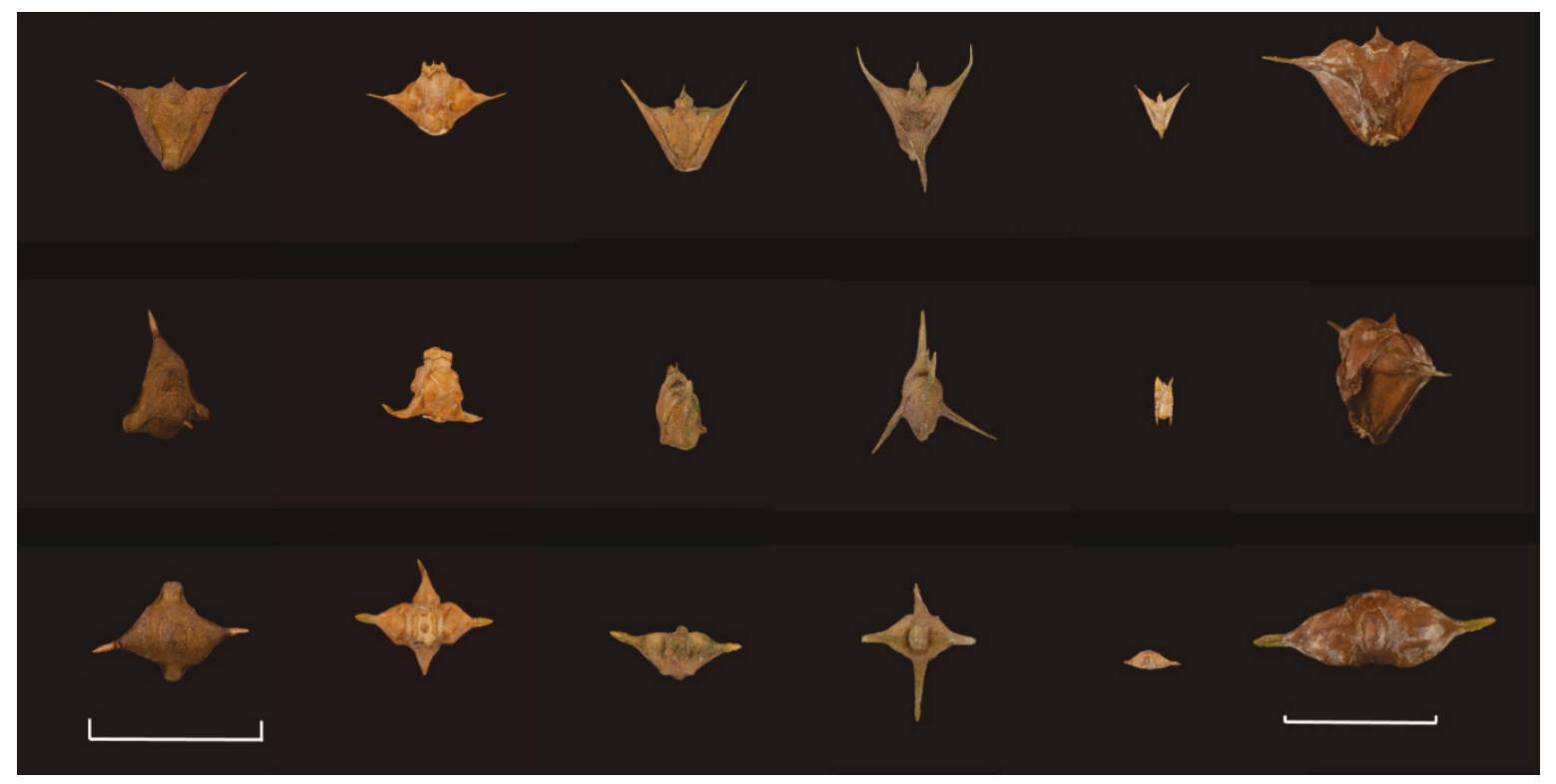


The U.S. Army Engineer Research and Development Center (ERDC) solves the nation's toughest engineering and environmental challenges. ERDC develops innovative solutions in civil and military engineering, geospatial sciences, water resources, and environmental sciences for the Army, the Department of Defense, civilian agencies, and our nation's public good. Find out more at www.erdc.usace.army.mil.

To search for other technical reports published by ERDC, visit the ERDC online library at http://acwc.sdp.sirsi.net/client/default.

Cover image: Dried fruits of water chestnut (species, population code). Top, left to right: Trapa natans, BR-MD-16; T. natans, CH-RI-16; T. sp 2, EM-KZN-16; T. incisa, NAK-16. Bottom: Trapa sp., WP-VA-16; T. japonica, ONO-J; T. natans var. pumila, ONO-J; T. natans, TEM-J. Photo Credit: Pablo Jimenez-Reyes. 


\section{Genetic and Morphological Differences between Water Chestnut (Myrtales: Lythraceae: Trapa) Populations in the Northeastern United States, Japan, and South Africa}

Lynde L. Dodd

Environmental Laboratory

U.S. Army Engineer Research and Development Center

3909 Halls Ferry Road

Vicksburg, MS 39180-6199

Nancy Rybicki

U.S. Geological Survey

12201 Sunrise Valley Drive

Reston, VA 20192

Ryan Thum

Montana State University

Department of Plant Sciences and Plant Pathology

313 Plant BioSciences Building

Bozeman, MT 59717-3150

Final report

Approved for public release; distribution is unlimited.
Yasuro Kadono

Kobe University

Department of Biology, Graduate School of Science

Rokkodai-cho 1-1

Nada, Kobe, 657-8501 Japan

Kadiera Ingram

George Mason University

4400 University Drive

Fairfax, VA 22030
Prepared for

U.S. Army Corps of Engineers

Washington, DC 20314-1000

Under

Work Unit 33143 


\section{Abstract}

Cryptic introductions are non-native species that have been introduced outside of native ranges; these introductions are undetected because the species have morphology similar to native or other non-native species naturalized within the same region. While non-native, invasive Trapa natans has been present in the Northeastern (NE) United States (U.S.) since the late 1800 s, unpublished data suggests a new introduction of Trapa has occurred in the Commonwealth of Virginia. This population was distinct: it had 2-spined fruit as opposed to the typical 4-spined fruit associated with $T$. natans. It was therefore suspected as a cryptic introduction of Trapa species.

This work aims to elucidate genetic and morphological differences of naturalized Trapa taxa (water chestnut) in the NE U.S. Comparisons of morphological characteristics and genetics were made between Trapa populations from the native regions of Eurasia and Africa versus those of the NE U.S. Results of the morphological analysis supported genetic results that 2-spine Trapa sp. and 4-spine T. natans in the U.S. were different, with the number of spines and the presence of a crown (Trapa sp. lacks a crown) as morphological taxonomic indicators.

Given the problems associated with introduced water chestnut in the U.S., further investigation into the genetic and ecological characteristics of each distinct taxa are warranted.

DISCLAIMER: The contents of this report are not to be used for advertising, publication, or promotional purposes. Citation of trade names does not constitute an official endorsement or approval of the use of such commercial products. All product names and trademarks cited are the property of their respective owners. The findings of this report are not to be construed as an official Department of the Army position unless so designated by other authorized documents. 


\section{Contents}

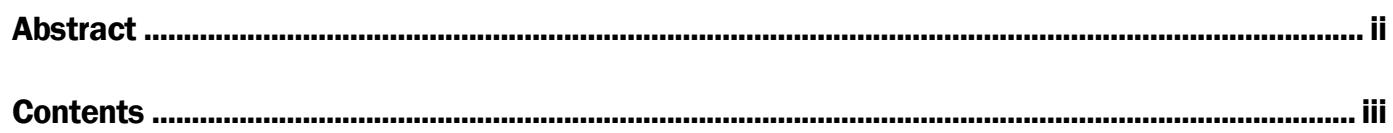

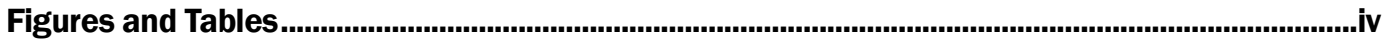

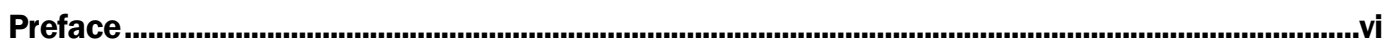

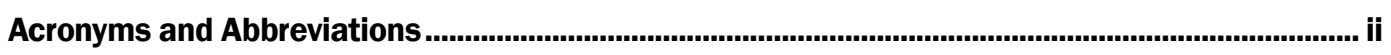

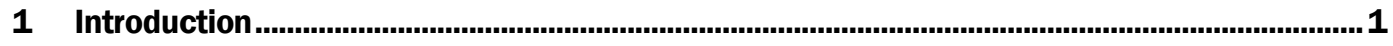

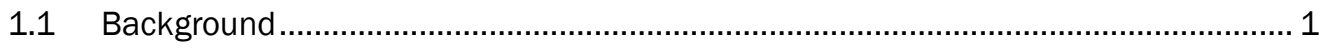

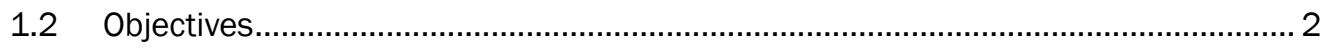

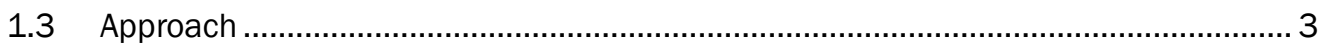

2 Genetic and Morphological Differences of Trapa taxa............................................................ 5

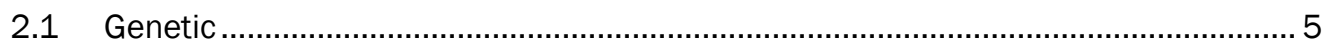

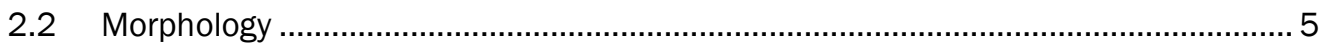

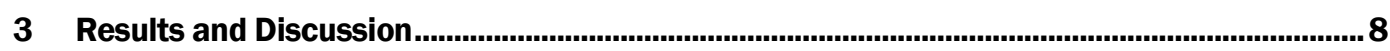

3.1 Genetic and morphological differences of Trapa taxa........................................ 8

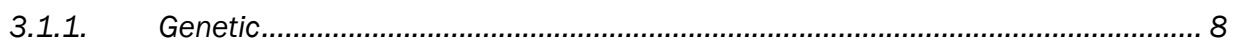

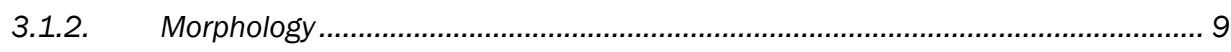

4 Conclusions.....................................................................................................................17

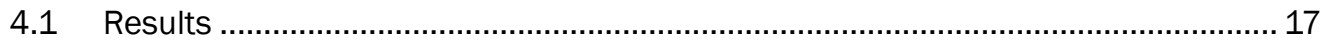

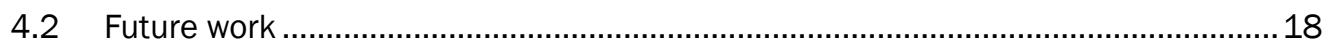

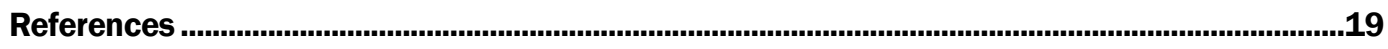

Appendix A: Raw Data Used in Morphology and Genetic Analyses ..............................................22

Report Documentation Page 


\section{Figures and Tables}

\section{Figures}

Figure 1. Trapa sp. 2-spine fruit (left) and pink flower (right) collected from the Potomac River September 201 Virginia.

Figure 2. Mode of measuring the size of fruit. A: angle $\left({ }^{\circ}\right)$ between upper spines. W: width of the fruit across upper spines. $\mathrm{H}$ : height of the fruit. $\mathrm{D}$ : thickness of the fruit. $\mathrm{L}$ : width across lower projections (pseudohorns or spines). B. Types of lower projections. I: Pseudohorns shorter than $2 \mathrm{~mm}$. II: Pseudohorns with the length between 2 and $4 \mathrm{~mm}$. III: Pseudohorns longer than $4 \mathrm{~mm}$. IV: Lower spines with acute apex. Illustration and descriptions from Kadono (1987).

Figure 3. Twenty-two populations of Trapa taxa were collected in 2016 from the U.S. ( $\mathrm{n}=$ 15), South Africa $(n=1)$, and Japan $(n=6)$.

Figure 4. Two-dimensional representation of principal coordinates analysis of amplified fragment length polymorphism for Trapa populations collected in 2016. Circles represent distinct separation.

Figure 5. Morphological characteristics by the seven genetic groups shown in Figure 4 and Table 3. A, Width of upper spines of fruit; B, Dry weight of fruit; C, Number of teeth on leaf; D, Width of stem below rosette; E, Percentage of 2, 3, or 4 spine fruits; F, Presence of fruit crown for populations in each of the genetic groups numbered 1 to 7 . The genetic group, putative species (location) and population for the groups are as follows: 1 is Trapa sp. (U.S.) WP-VA, VCB-VA; 2 is Trapa sp. (U.S.) ML-VA; 3 is T. natans (U.S.) BR-MD ${ }^{1}, \mathrm{CH}-\mathrm{RI}$, CP-RI, IB-NY, SC-NY, TP-NY, MM-NY, SSB-NY, RC-NY, CDL-VT, CCD-NY, CMB-NY; 4 is T. natans (Japan) TEM-J, KO-J; 5 is T. japonica, T. natans var pumila (Japan) MIK-J1', IWA-J, ONO-J; 6 is T. incisa (Japan) NAK-J; 7 is Trapa sp. 2 (S. Africa) EM-KZN¹. Each bar represents the mean \pm standard error for panels A-D.

Figure 6: A, Lower projection - apex; B, Lower Projection - length category; C, Lower projection - extending direction; $\mathrm{D}$, Number of acute spines for populations in each of the genetic groups numbered 1 to 6 . The genetic groups are described in Figure 4 and Table 3. The genetic group, putative species (location) and population for the groups are as follows: 1 is Trapa sp. (U.S.) WP-VA, VCB-VA; 2 is Trapa sp. (U.S.) ML-VA; 3 is T. natans (U.S.) BR-MD1 ${ }^{1}, \mathrm{CH}-\mathrm{RI}, \mathrm{CP}-\mathrm{RI}$, IB-NY, SC-NY, TP-NY, MM-NY, SSB-NY, RC-NY, CDL-VT, CCD-NY, CMB-NY; 4 is T. natans (Japan) TEM-J, KO-J; 5 is T. japonica, T. natans var pumila (Japan) MIK-J1, IWA-J, ONO-J; 6 is T. incisa (Japan) NAK-J; 7 is Trapa sp. 2 (S. Africa) EM-KZN12.

Figure 7: Mean \pm standard deviation for leaf and fruit characteristics. A, total number of teeth on leaf; B, Average dry weight of the fruits; C, Average width across upper spines; D, Average width across lower projections; E, Average height; F, Average thickness for populations in each of the genetic groups numbered 1 to 6 . The genetic groups are described in Figure 4 and Table 3. The genetic group, putative species (location) and population for the groups are as follows: 1 is Trapa sp. (U.S.) WP-VA, VCB-VA; 2 is Trapa sp. (U.S.) ML-VA; 3 is T. natans (U.S.) BR-MD11, CH-RI, CP-RI, IB-NY, SC-NY, TP-NY, MM-NY, SSBNY, RC-NY, CDL-VT, CCD-NY, CMB-NY; 4 is T. natans (Japan) TEM-J, KO-J; 5 is T. japonica, T. natans var pumila (Japan) MIK-J1, IWA-J, ONO-J; 6 is T. incisa (Japan) NAK-J; 7 is Trapa sp. 2 (S. Africa) EM-KZN1

\section{Tables}

Table 1. Populations of Trapa taxa collected in 2016 for this study (*indicates 11 to 12 corresponding quality fruits available for morphological analysis). 
Table 2. Morphological characteristics observed and recorded for Trapa specimens collected in 2016.

Table 3. Summary of genetic groups, species, country, populations, and selected morphological parameters. ND = no data.

Table A-1. Principal Coordinates Analysis -- X, Y data for Axis 1 and Axis 2 for Figure 4.

Table A-2a. Summary of populations sampled and their respective genetic groups,

species, latitude, and longitude.

Table A-2b. Summary of selected morphological parameters by population and genetic group ( $\mathrm{N}=$ number of samples, $\mathrm{nd}=$ no data).

Appendix Table A-2c. Sample size (N), average, and standard error (SE) of selected morphological parameters by population and genetic group ( $\mathrm{nd}=$ no data).

Appendix Table A-2c - continued. Sample size (N), average, and standard error (SE) of selected morphological parameters by population and genetic group ( $\mathrm{nd}=$ no data). 


\section{Preface}

This study was conducted for the Aquatic Plant Control Research Program (APCRP). The APCRP is sponsored by Headquarters, U.S. Army Corps of Engineers (HQUSACE), and is assigned to the U.S. Army Engineer Research and Development Center (ERDC) under the purview of the Environmental Laboratory (EL), Vicksburg, Mississippi. The APCRP Program Manager is Dr. Linda Nelson.

The authors would like to thank Ms. Julie Nachtrieb and Mr. Aaron Schad for their review of this manuscript including the following: Mr. John Odenkirk, Virginia Game and Inland Fisheries; Dr. Grant Martin and Mr. Alex Searle, Rhodes University; Ms. Ann Bove, Vermont Department of Environmental Conservation; Mr. Robert Naczi, New York Botanical Garden; Mr. Marek Topolski and Mr. Mark Lewandowski, Maryland Department of Natural Resources; Ms. Kathryn DesJardin, Hobart and William Smith College and Partnership for Regional Invasive Species Management; Ms. Katie DeGoosh-DiMarzio; Ms. Michele Dobson, Harford County Department of Public Works; Ms. Andrea Davalos, Cornell College; and Mr. Justin Redman, student volunteer, all for their Trapa specimen contributions. The authors would also like to thank the USACE Baltimore District, the U.S. Geological Survey National Research Program, and the Montana State University Plant Sciences and Plant Pathology Department for their support.

This report was prepared under the general supervision of Dr. Timothy E. Lewis, chief, Aquatic Ecology and Invasive Species Branch (CEERD-EEA); Mr. Mark D. Farr, chief, Ecosystem Evaluation and Engineering Division (CEERD-EE); and Dr. Ilker R. Adiguzel, Director, EL.

At the time of the publication of this report, COL Ivan P. Beckman was the Commander of ERDC, and Dr. David W. Pittman was the Director. 


\section{Acronyms and Abbreviations}

\begin{tabular}{|l|l|}
\hline Acronym & \multicolumn{1}{|c|}{ Meaning } \\
\hline AFLP & Amplified Fragment Length Polymorphisms \\
\hline APCRP & Aquatic Plant Control Research Program \\
\hline DNA & Deoxyribonucleic Acid \\
\hline DoD & Department of Defense \\
\hline EE & Ecosystem Evaluation and Engineering Division \\
\hline EEA & Aquatic Ecology and Invasive Species Branch \\
\hline EL & Environmental Laboratory \\
\hline ERDC & Engineer Research and Development Center \\
\hline NE & Northeastern \\
\hline PCoA & Principal Coordinates Analysis \\
\hline TR & Technical Report \\
\hline U.S. & United States \\
\hline USGS & U.S. Geological Survey \\
\hline HQUSACE & Headquarters, U.S. Army Corps of Engineers \\
\hline
\end{tabular}




\section{Introduction}

\subsection{Background}

Native to Eurasia and Africa, water chestnut (Myrtales: Lythraceae: Trapa L.) (Graham 2005; ITIS 2015; USDA 2016) is an annual, floating-leaved aquatic plant (Pemberton 2002; Crow and Hellquist 2000; Hummel and Kiviat 2004). Considered invasive in the United States (U.S.), its aggressive growth negatively influences aquatic ecosystem biodiversity and function and impedes hydroelectric power generation, irrigation, and recreation (Rawls 1964a, b; Carter and Rybicki 1994; Caraco and Cole 2002; Pemberton 2002; Naylor 2003; Hummel and Kiviat 2004; Ding and Blossey 2005; Hummel and Findlay 2006; LaManche 2007). Water chestnut has been reported in a number of states in the U.S., including Connecticut, Delaware, Massachusetts, Maryland, New Hampshire, New Jersey, New York, Pennsylvania, Rhode Island, Vermont, Virginia, and the District of Columbia (EDDMaps 2017; Pfingsten et al. 2017). The plant has been particularly problematic in the Northeastern (NE) U.S. since shortly after its introduction during the latter half of the $19^{\text {th }}$ century (Gwathmey 1945; Carter and Rybicki 1994; Les and Mehrhoff 1999; Naylor 2003). Although it has not been listed as a federal noxious weed, the following states have proactively listed water chestnut as noxious and/or prohibited: Alabama, Arizona, Connecticut, Delaware, Florida, Idaho, Illinois, Maine, Maryland, Massachusetts, Michigan, Minnesota, New Hampshire, New York, North Carolina, Oregon, Pennsylvania, South Carolina, Tennessee, Vermont, Virginia, Washington, and Wisconsin (EDDMaps 2017; Pfingsten et al. 2017).

While only one species of Trapa was known to be introduced to the U.S. (Trapa natans) (EDDMaps 2017; Pfingsten et al. 2017), a morphologically distinct population was discovered in Gunston Cove on the Potomac River within the Commonwealth of Virginia (Figure 1; Rybicki 2017 unpublished data). This population was distinct in that it had 2-spined fruit as opposed to the typical 4-spined fruit associated with $T$. natans and was therefore suspected as a cryptic introduction of Trapa species ${ }^{1}$. Further investigation into the distribution of this led to additional observations of

\footnotetext{
1 Rybicki, N. 2014. Personal communication with Nathan Harms via email. 9 September 2014. USGS and USACE ERDC.
} 
populations in Virginia of the 2-spined Trapa (hereafter referred to as Trapa sp.). The 2-spined Trapa sp. is not morphologically different from descriptions of T.japonica (Kadono 1987; Kadono 2018). However, the taxonomy and species identification of Trapa is confusing due to the wide variability in morphological traits (Kim et al. 2010; Li et. al 2017). Cook (1990) indicated there may be only one polymorphic species or up to 20 species worldwide within the genus. There also appears to be many synonyms in different geographic regions (Kadono 1987). Therefore, it is unclear whether the 2-spine Trapa sp. is a morphological variant of $T$. natans, or whether it is a genetically distinct and cryptic species of Trapa.

Figure 1. Trapa sp. 2-spine fruit (left) and pink flower (right) collected from the Potomac River September 201 Virginia.

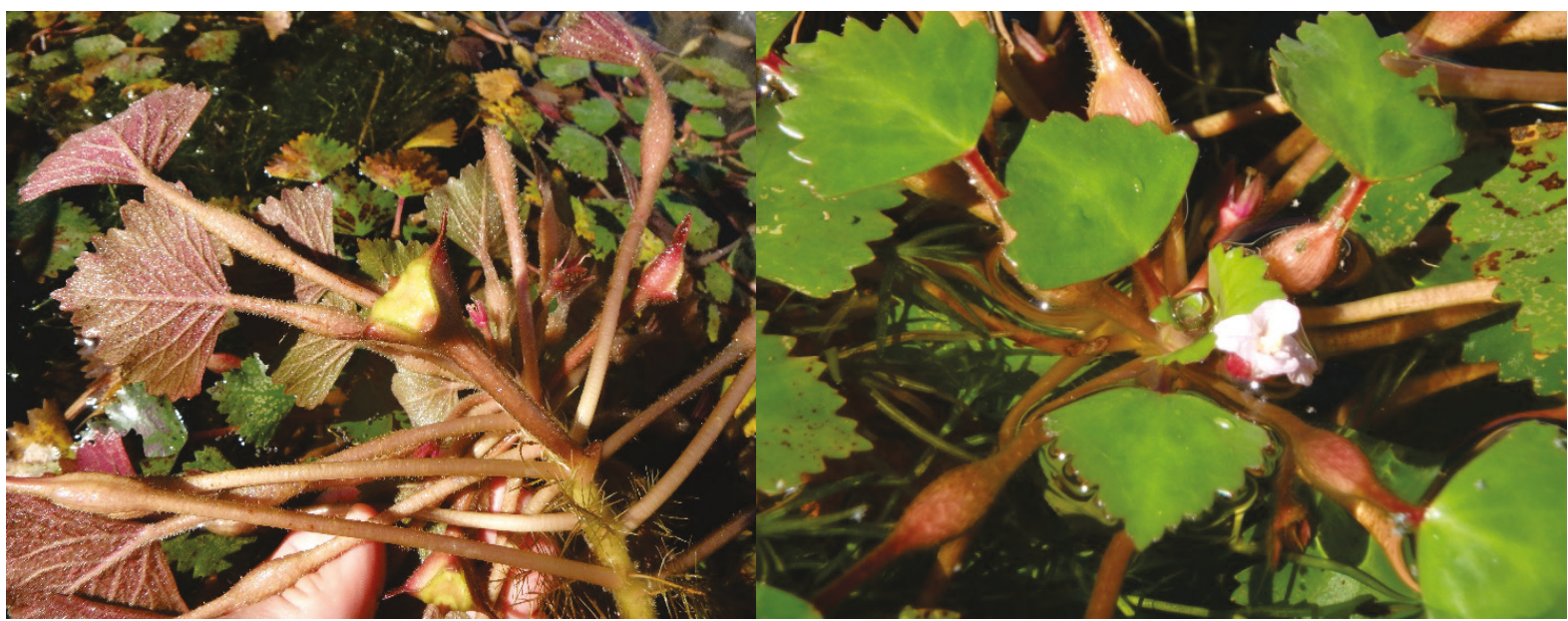

Determining whether the 2-spined and 4-spined Trapa in the U.S. are distinct, cryptic taxa is important for effectively managing them. Currently, management strategies used to control Trapa in the U.S. (whether physical, chemical, or biological) are based upon the understanding that Trapa natans is the only Trapa taxon found in the U.S. Differences in phenology or ecology (i.e., anthesis, biomass, number of fruit produced, and/or competitive ability) of cryptic species can potentially affect the implementation and effectiveness of management strategies employed by water resource managers.

\subsection{Objectives}

The objectives of this work were the following: (1) determine the genetic and morphological differences of Trapa taxa in the NE U.S., (2) compare those to Trapa populations from native and introduced regions of Eurasia 
and Africa, and (3) summarize variation in morphological characteristics of genetically distinct groups and populations of Trapa in this study.

\subsection{Approach}

Trapa collection. Specimens of the genus Trapa were collected in the 2016 growing season (June through November) from a variety of populations by U.S. Geological Survey (USGS) and U.S. Army Corps of Engineers (USACE) researchers, and including other numerous collaborators (Table 1). Varying numbers of rosettes were collected in the field (3-30, depending on availability) at least 1 to 2 meters apart to avoid sampling the same plant, with at least one mature, fully ripe fruit (when available) for each population. For populations within the U.S., each rosette was rinsed and placed into a labeled plastic bag and shipped overnight in coolers to USGS (Reston, VA) for morphological evaluation. Specimens from outside the U.S. were dried prior to shipment. One to three leaves from each rosette were dried in silica gel and sent to Montana State University for molecular analysis. The putative species for Japanese specimens were assigned based on the width of the fruit and followed the nomenclature in Table 1 of Takono and Kadono (2005). The nomenclature for specimens collected in the U.S. from NY, RI, and VT follows Britton and Brown (1970), but was not specified for specimens collected in VA and will be referred to as Trapa sp. Specimens from S. Africa did not have mature fruits, were not identified to species, and will be referred to as Trapa sp. 2 in this technical report (TR).

\subsection{Availability of specimens}

Pressed specimens, dried leaves, and fruits are archived and available on request by contacting the author, Ms. Lynde Dodd, ERDC-EL. Pressed specimens of Trapa sp. (Fairfax County, VA, collected in 2015) and T. natans (Baltimore County, MD, collected in 2015) are also available at George Mason University Herbarium, Fairfax, VA (digital images on-line: http://sernecportal.org/portal/index.php\#). Specimens and data related to DNA are archived and available upon request by contacting Dr. Ryan Thum, Montana State University. 
Table 1. Populations of Trapa taxa collected in 2016 for this study (*indicates 11 to 12 corresponding quality fruits available for morphological analysis).

\begin{tabular}{|c|c|c|c|c|}
\hline Population Code & Country & County, City, District & State, Prefecture & Putative Species \\
\hline WP-VA-16* & U.S. & Fairfax & VA & Trapa sp. \\
\hline VCB-VA-16* & U.S. & Fairfax & VA & Trapa sp. \\
\hline ML-VA-16* & U.S. & Fairfax & VA & Trapa sp. \\
\hline BR-MD-16 & U.S. & Baltimore & MD & Trapa natans \\
\hline CH-RI-16* & U.S. & Washington & RI & Trapa natans \\
\hline CP-RI-16* & U.S. & Providence & $\mathrm{RI}$ & Trapa natans \\
\hline IB-NY-16* & U.S. & Greene & NY & Trapa natans \\
\hline SC-NY-16* & U.S. & Columbia & NY & Trapa natans \\
\hline TP-NY-16* & U.S. & Albany & NY & Trapa natans \\
\hline MM-NY-16* & U.S. & Cayuga & NY & Trapa natans \\
\hline SSB-NY-16* & U.S. & Wayne & NY & Trapa natans \\
\hline RC-NY-16* & U.S. & Wayne & NY & Trapa natans \\
\hline CDL-VT-16* & U.S. & Rutland & VT & Trapa natans \\
\hline CCD-NY-16* & U.S. & Washington & NY & Trapa natans \\
\hline CMB-NY-16* & U.S. & Warren & NY & Trapa natans \\
\hline TEM-J-16* & Japan & Kako & Hyogo & Trapa natans \\
\hline KO-J-16* & Japan & Kobe City & Hyogo & Trapa natans \\
\hline IWA-J-16* & Japan & Kobe City & Hyogo & Trapa japonica \\
\hline ONO-J-16* & Japan & Ono City & Hyogo & $\begin{array}{l}\text { Trapa japonica dominant } \& \\
\text { Trapa natans var. pumila }\end{array}$ \\
\hline MIK-J-16 & Japan & Mikata & Fukui & $\begin{array}{l}\text { Trapa japonica \& Trapa } \\
\text { natans var. pumila mixed }\end{array}$ \\
\hline NAK-J-16* & Japan & Tsuruga City & Fukui & Trapa incisa \\
\hline EM-KZN-16 & South Africa & Empangeni & KwaZulu-Natal & Trapa sp. 2 \\
\hline
\end{tabular}

*indicates 11 to 12 corresponding quality fruits available for morphological analysis 


\section{Genetic and Morphological Differences of Trapa taxa}

\subsection{Genetic}

Both introduced and native Trapa taxa specimens collected in 2016 for this project were processed for genetic analysis using amplified fragment length polymorphisms (AFLPs). For each of the 22 populations, one to six individuals and one duplicate was sampled for Deoxyribonucleic acid (DNA). DNA was extracted using Qiagen DNeasy Plant DNA extraction kits. Preparation of AFLPs followed Thum et al. (2011) using 100 ng of total genomic DNA and two primer pairs (EcoR1-CGA/Mse1-AGG and EcoR1-CTG/Mse1-AGG). In order to estimate scoring error rates, duplicate AFLPs were performed on approximately $20 \%$ of all samples.

Amplified fragment length polymorphism data were scored with GeneMapper v4.o (Applied Biosystems) and analysis of fragments was limited between 100 and 500 base pairs in length. SpAGedi version 1.5 (Hardy and Vekemans 2002) was used to remove loci, which were not repeatable by estimating heritability in the subset of samples for which there were duplicates using $\mathrm{F}_{\mathrm{ST}} \geq 0.8$. The final dataset for this analysis contained 475 AFLP markers. Principal Coordinates Analysis (PCoA), as implemented in GenAlEx 6.5 (Peakall and Smouse 2006, 2012) was used to analyze the AFLP dataset (no a priori groupings were determined for the PCoA, distances were standardized, and covariance method was used for this analysis).

\subsection{Morphology}

For each of the 22 populations, measurements of the morphological attributes of specimens of Trapa were made to quantify taxonomic characteristics to differentiate potentially genetically distinct groups of specimens or populations following the procedure of Kadono (1987) (Table 2 and Figure 2). In addition to the procedure used by Kadono (1987), for each rosette sampled, the following observations were recorded using the following fresh specimens: the width of stem below the rosette (within 10-20 cm from the base), flower petal color, and the color of the abaxial surface of leaves. 
Figure 2. Mode of measuring the size of fruit. A: angle $\left({ }^{\circ}\right)$ between upper spines. W: width of the fruit across upper spines. H: height of the fruit. D: thickness of the fruit. L: width across lower projections (pseudohorns or

spines). B. Types of lower projections. I: Pseudohorns shorter than $2 \mathrm{~mm}$. II: Pseudohorns with the length between 2 and $4 \mathrm{~mm}$. III: Pseudohorns longer than $4 \mathrm{~mm}$. IV: Lower spines with acute apex. Illustration and descriptions from Kadono (1987).

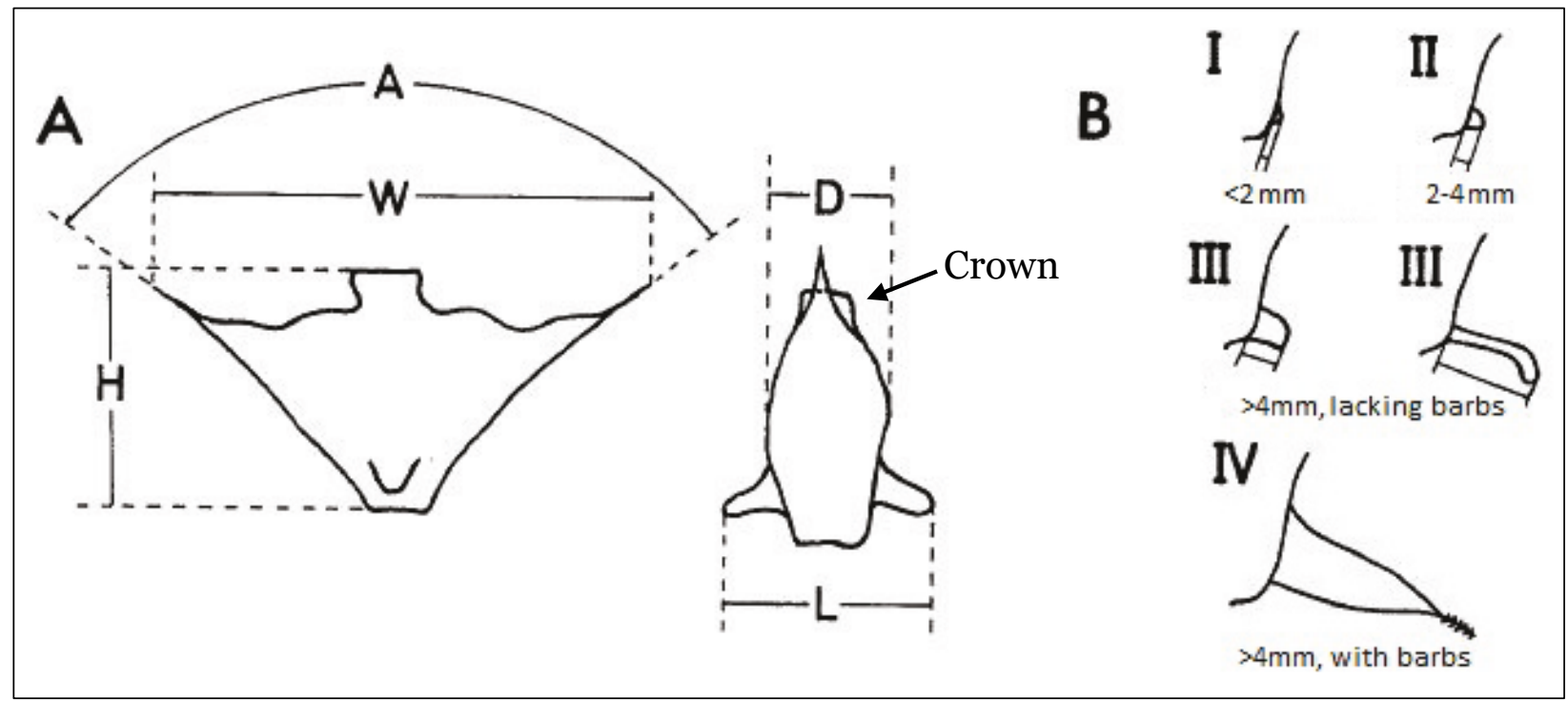

Table 2. Morphological characteristics observed and recorded for Trapa specimens collected in 2016.

\begin{tabular}{|l|l|}
\hline Plant part & Morphological description \\
\hline Leaf & $\begin{array}{l}\text { Color (underside); teeth (count) } \\
\text { Color (petal) } \\
\text { Fruit } \\
\text { General }\end{array}$ \\
$\begin{array}{l}\text { Crown (presence); dry weight (g); height (mm); thickness (mm); } \\
\text { number of spines }\end{array}$ \\
$\begin{array}{l}\text { Width (mm); orientation (ascending, descending, horizontal) } \\
\text { Upper horn reflex (presence) }\end{array}$ \\
Stem & $\begin{array}{l}\text { Apex (acute, obtuse, both, none); base (narrow, wide, combination, } \\
\text { none); orientation (ascending, descending, horizontal, none, } \\
\text { undetermined); width (mm), length (mm) }\end{array}$ \\
& \begin{tabular}{l} 
Width (mm) below rosette \\
\hline
\end{tabular}
\end{tabular}

Additionally, one typical leaf was selected-representative in size and overall appearance of its rosette-and the number of teeth was counted. At least one mature fruit was selected for each rosette and dried. The following observations were recorded using dried fruits (see Figure 2): dry weight, presence or absence of a crown, the number of spines, width across upper spines, width across lower projections, height, thickness (across 
main fruit body), angle and orientation of upper spines, lower projection length and type, shape of lower projection apex, shape of lower projection base (where projection meets main fruit body), and presence or absence of an oxbow-like or recurving shape in the upper spines. Furthermore, the presence and severity of any shriveling or damage to each fruit was noted, and those fruits that were not shriveled during drying or did not have sufficient damage to effect a measurement were considered quality fruit. For each population, the first 11 or 12 rosettes collected that had quality fruits were distinguished from the others and selected for morphological and genetic analysis and used to summarize correspondence between morphological and genetic characteristics. Fruit characteristics for three populations, BR-MD ( $n=5)$, MIK-J ( $n=8)$, and EM-KZN ( $n=1)$ were not included in the summary of fruit morphology because they did not have a sufficient number of quality fruits to represent the variability of a population. 


\section{Results and Discussion}

\subsection{Genetic and morphological differences of Trapa taxa}

Specimens from 22 populations of six putative species from both the introduced and native ranges of Trapa taxa were included in the study (Figure 3, Table 1).

Figure 3. Twenty-two populations of Trapa taxa were collected in 2016 from the U.S. $(n=$ $15)$, South Africa $(n=1)$, and Japan $(n=6)$.
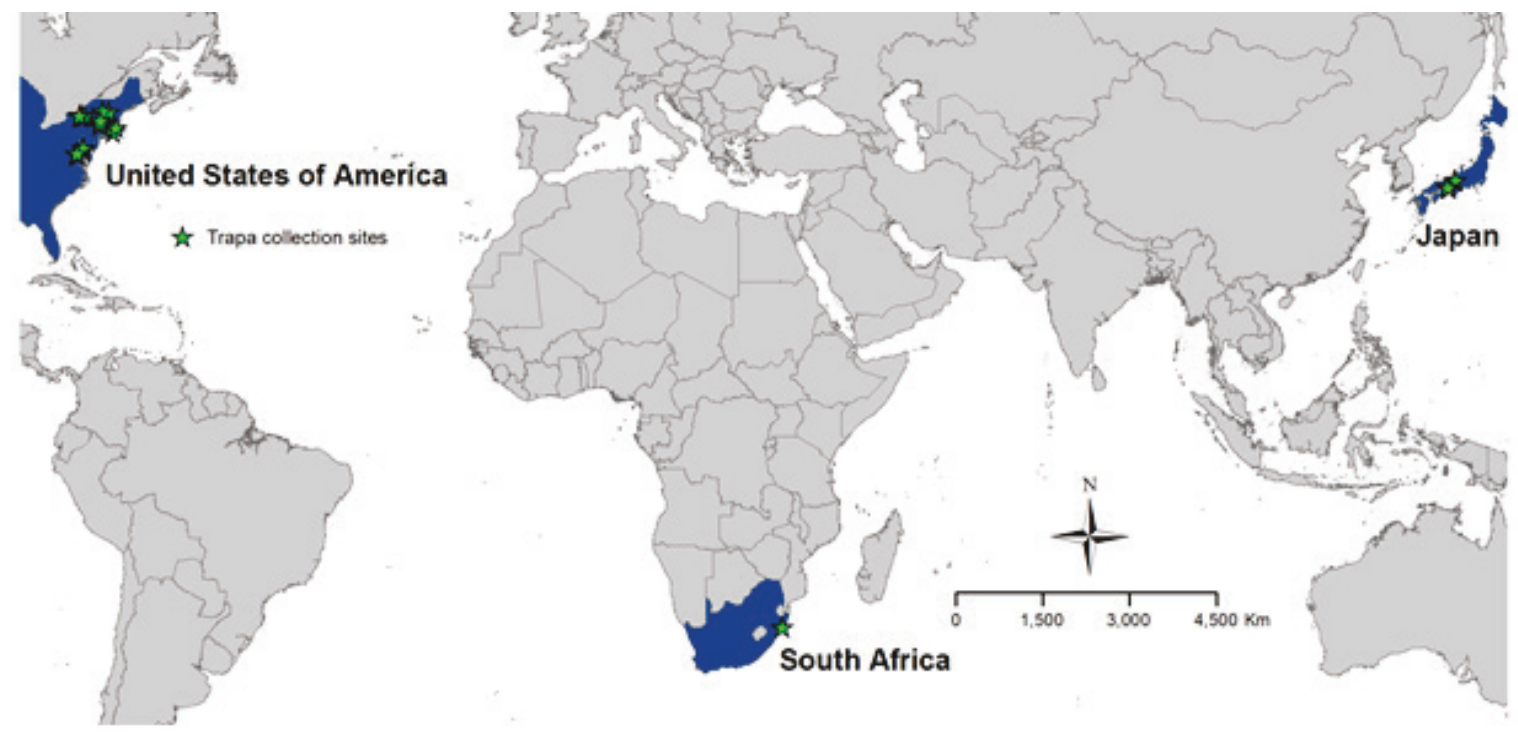

\subsubsection{Genetic}

Amplified fragment length polymorphism data analysis showed a clear genetic separation between the newly discovered 2-spine Trapa sp. and 4-spine T. natans in the U.S., confirming them as genetically distinct (PCoA Axis 1 and 2 explained 33\% and 8\% of the variation, respectively, Figure 4, Appendix Table 1). U.S. Trapa taxa were also compared to four taxa collected from Japan (T. incisa, T. natans, T. natans var. pumila, and T.japonica), and one unidentified species collected from South Africa (Trapa sp. 2, EM-KZN-16). U.S. populations identified as T. natans did not show a genetic affinity to Japanese samples identified as T. natans, indicating a possible cryptic introduction within what is currently recognized as T. natans. The U.S. 2-spine Trapa sp. taxon did show a genetic affinity to Japanese samples identified as $T$.japonica and $T$. natans var. pumila, although they were separated along axis 2 of the PCoA. One Trapa sp. U.S. population, ML-VA, showed genetic separation from all other species, indicating the potential for yet another cryptic introduction, or possibly a hybrid between Trapa natans and Trapa sp. in 
the U.S. The genetic analysis differentiated seven groups used for discussion of morphology (Table 3).

Figure 4. Two-dimensional representation of principal coordinates analysis of amplified fragment length polymorphism for Trapa populations collected in 2016. Circles represent distinct separation.

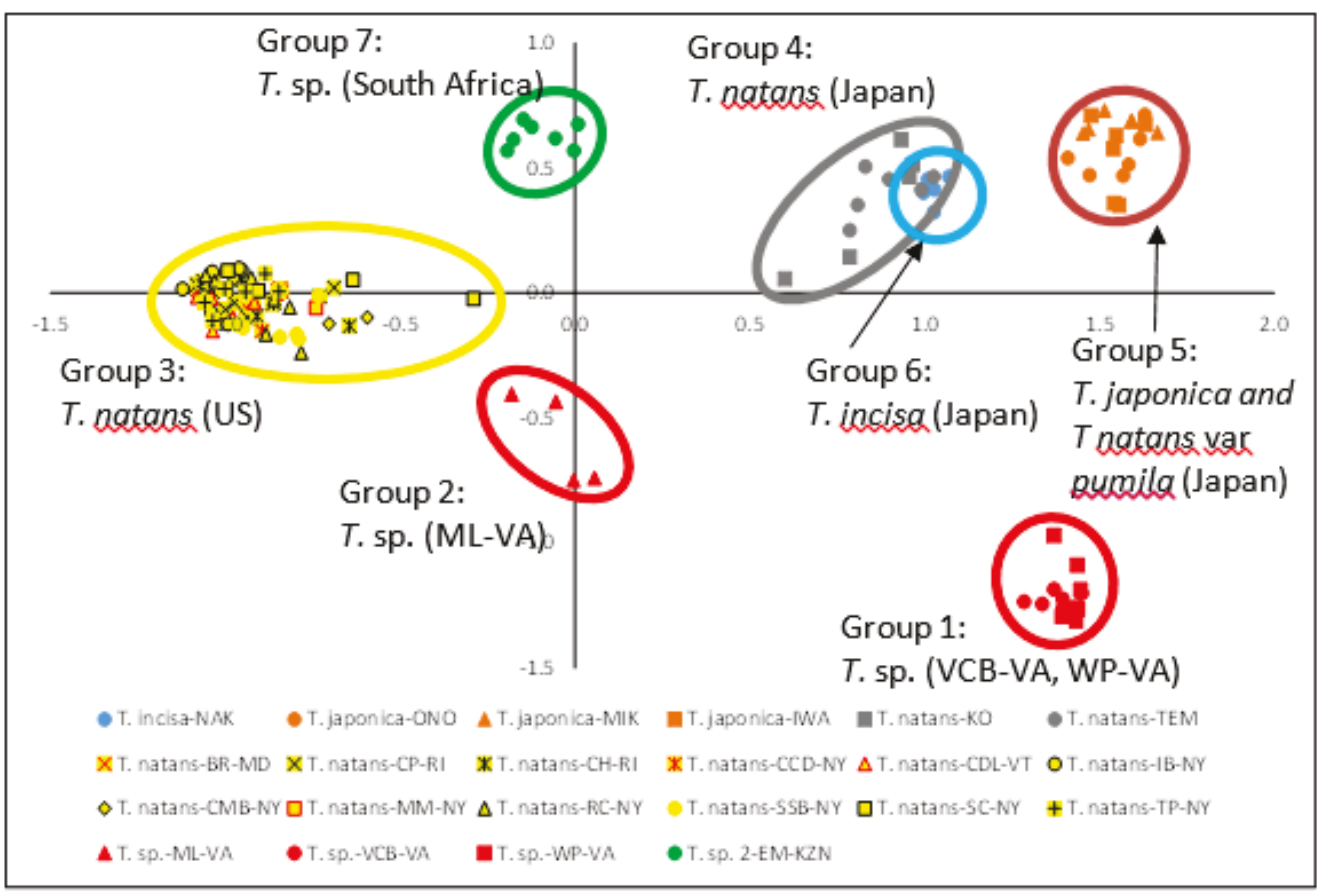

\subsubsection{Morphology}

A summary of morphology by genetic groups (groups are described in Table 3 and Figure 4). While the genetic analysis differentiated the population of Trapa sp. in ML-VA (group 2) as a separate group from Trapa sp. in WP-VA and ML-VA (group 1), the morphological characteristics were not different (Figure 5 A to F). The U.S. Trapa sp. groups from populations in Virginia had similar width of upper spines, dry weight of fruit, number of teeth on the leaf, width of stem, and percentage of 2-spine fruits. Trapa sp., however, was morphologically different from the group of T. natans in the U.S. (group 3) and from all other groups because Trapa sp. lacked a crown on the fruit (Figure $5 \mathrm{~F}$ ), the underside of the leaf was dark red, and flowers were pink (Table 3). In contrast to Trapa sp. in the U.S., for all other genetic groups and populations in the U.S. or Japan, a crown was consistently present (except for NAK-J), the underside of the leaf was green (or green and brown), and flowers were described as white. Six of the individuals were lacking a crown in group 3 
and those were in the three populations, $\mathrm{RC}-\mathrm{NY}(\mathrm{n}=1), \mathrm{MM}-\mathrm{NY}(\mathrm{n}=4)$, and $\mathrm{SC}-\mathrm{NY}(\mathrm{n}=1)$.

Table 3. Summary of genetic groups, species, country, populations, and selected morphological parameters. $\mathrm{ND}=$ no data.

\begin{tabular}{|c|c|c|c|c|}
\hline $\begin{array}{l}\text { Genetic } \\
\text { group }\end{array}$ & Putative species & Populations & Flower color & Color on underside of leaf \\
\hline 1 & $\begin{array}{l}\text { Trapa sp. } \\
\text { (U.S.) }\end{array}$ & WP-VA, VCB-VA & Pink & Dark red \\
\hline 2 & $\begin{array}{l}\text { Trapa sp. } \\
\text { (U.S.) }\end{array}$ & ML-VA & Pink & Dark red \\
\hline 3 & $\begin{array}{l}\text { Trapa natans } \\
\text { (U.S.) }\end{array}$ & $\begin{array}{l}\text { BR-MD1 }{ }^{1} \text { CH-RI, CP-RI, IB- } \\
\text { NY, SC-NY, TP-NY, MM- } \\
\text { NY, SSB-NY, RC-NY, CDL- } \\
\text { VT, CCD-NY, CMB-NY }\end{array}$ & White & Green and brown \\
\hline 4 & $\begin{array}{l}\text { Trapa natans } \\
\text { (Japan) }\end{array}$ & TEM-J, KO-J & White & $\begin{array}{l}\text { Green with pink veins, } \\
\text { Green and brown }\end{array}$ \\
\hline 5 & $\begin{array}{l}\text { Trapa japonica, Trapa } \\
\text { natans var pumila } \\
\text { (Japan) }\end{array}$ & MIK-J1, IWA-J, ONO-J & White & Green and brown \\
\hline 6 & $\begin{array}{l}\text { Trapa incisa } \\
\text { (Japan) }\end{array}$ & NAK-J & White & Green \\
\hline 7 & $\begin{array}{l}\text { Trapa sp. } 2 \\
\text { (S. Africa) }\end{array}$ & EM-KZN1 & ND & Green and brown \\
\hline
\end{tabular}

IInsufficient number of quality fruits to summarize fruit morphology in the population

The Japanese $T$. incisa (group 6) fruit was the smallest in width and dry weight (Figure 5 A and B). The S. African Trapa sp. 2 (group 7) had no flowers present and the only fruit present was lacking a crown and had two spines. This population had a leaf teeth count of $<20$ (Figure $5 \mathrm{C}$ ) and the underside of the leaf was green and brown (Table 3). The stem width was $5 \mathrm{~mm}$ or less for both the S. African Trapa sp. 2 (group 7) and U.S. Trapa sp. (groups 1 and 2), while it was three times the width in T. natans in the U.S. (group 3) (Figure 5 D). Fruits with two spines, characteristic of Trapa sp., were also prevalent in two of the Japanese groups, the T. natans (group 4) and T. natans var pumila and T.japonica (group 5). However, the U.S. T. natans (group 3) and the Japanese T. incisa (group 6) groups had 4 spines (Figure 5 E).

The U.S. T. natans (group 3) had lower values than the Japanese T. natans (group 4) for fruit width and weight, and number of teeth on the leaf, and had a greater percentage of 4-spine fruit (Figure 5 A-C, E). The Japanese $T$. natans (group 4) had greater values than the Japanese T. japonica and T. natans var pumila (group 5) or T. incisa (group 6) for fruit width and 
weight and the number of teeth on the leaf. The percentage of 4-spine fruit was $100 \%$ for $T$. incisa (group 6), and the number of spines varied between 2-spine and 4-spine for other Japanese groups (groups 4 and 5). 
Figure 5. Morphological characteristics by the seven genetic groups shown in Figure 4 and Table 3. A, Width of upper spines of fruit; B, Dry weight of fruit; C, Number of teeth on leaf; D, Width of stem below rosette; E, Percentage of 2, 3, or 4 spine fruits; F, Presence of fruit crown for populations in each of the genetic groups numbered 1 to 7 . The genetic group, putative species (location) and population for the groups are as follows: 1 is Trapa sp. (U.S.) WP-VA, VCB-VA; 2 is Trapa sp. (U.S.) ML-VA; 3 is T. natans (U.S.) BR-MD ${ }^{1}$, CH-RI, CP-RI, IB-NY, SC-NY, TP-NY, MM-NY, SSB-NY, RC-NY, CDL-VT, CCD-NY, CMB-NY; 4 is T. natans (Japan) TEM-J, KO-J; 5 is $T$. japonica, T. natans var pumila (Japan) MIK-J1, IWA-J, ONO-J; 6 is T. incisa (Japan) NAKJ; 7 is Trapa sp. 2 (S. Africa) EM-KZN1 . Each bar represents the mean \pm standard error for panels A-D.

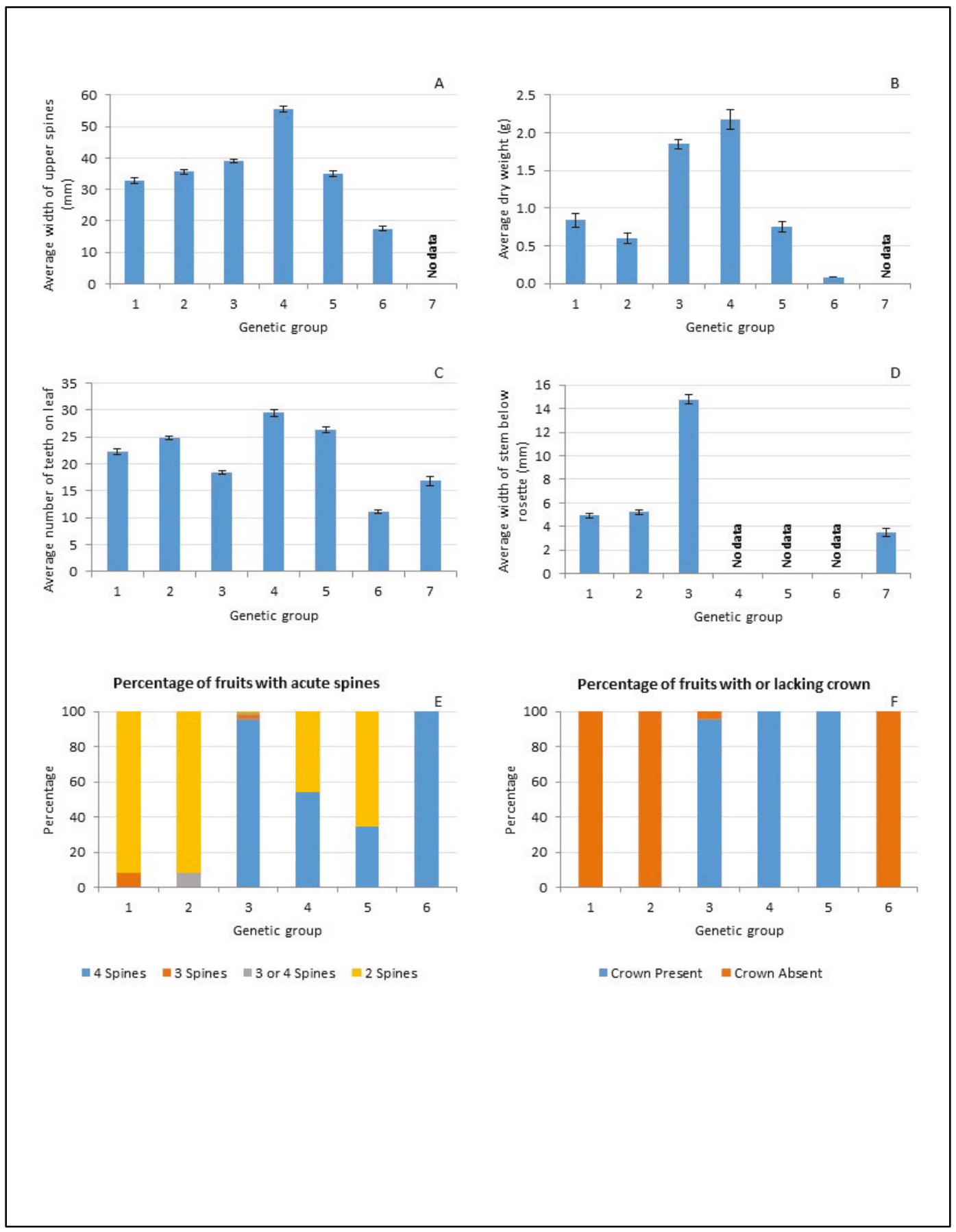


Summary by population (populations are described in Table 1 and Appendix Table 2a, $b$, and c; genetic groups are described in Table 3 and Figure 4). For the nineteen populations with sufficient quality fruits, the qualitative (Figure 6) and quantitative (Figure 7) morphological parameters were summarized in plots. The populations shown in the plots (Figures $5-7$ ) are arranged and labeled on the $x$-axis by the seven genetic groups identified in Figure 4, and groups are numbered in order of the latitude of each population in the group. By arranging them by latitude, the groups collected in the same country are adjacent and can be examined to determine whether proximity in latitude helps explain patterns of the variation in the morphological characteristics.

Upper and lower spine characteristics. The lower projection apex was generally obtuse in U.S. Trapa sp. (group 1 and 2), Japanese T. japonica and $T$. natans var. pumila (group 5) populations and was generally acute in U.S. T. natans (group 3) and Japanese T. incisa (group 6) populations (Figure $6 \mathrm{~A}$ ). The upper spine orientation showed little variation and was ascending in all populations except where the upper spine was descending at KO-J in group 5. The lower projection length was highly variable among sites; however, the U.S. Trapa sp. (group 1) and Japanese T. incisa (groups 6) were similar in this trait (Figure 6 B). The lower projection base showed little variation and was wide at all sites, except the base was narrow on one of the fruits at site ML-VA and ONO-J. The lower projection's extending direction was horizontal for U.S. Trapa sp. (group 1 and 2), and the extending direction was less variable than at other sites (Figure 6 C). All fruits in Japan (with the exception of NAK-J) and the NE U.S. had a crown, while none of the Trapa sp. at any Virginia sites had a crown. Populations of T. natans in the U.S. had 4-spine fruits with few exceptions; there were rarely 3 -spine fruits at two populations and a 2spine fruit at one population (Figure 6D). Two-spine fruits were prevalent for U.S. Trapa sp. (group 1 and 2), except there were several 3-spine fruits at VCB-VA, and there was one 4-spine fruit at ML-VA. Two-spine fruits were also prevalent at Japanese populations ONO-J and IWA-J for $T$. japonica or T. natans var. pumila (group 5) and at KO-J, one of two Japanese populations with T. natans (group 4). 
Figure 6. A, Lower projection - apex; B, Lower Projection - length category; C, Lower projection - extending direction; D, Number of acute spines for populations in each of the genetic groups numbered 1 to 6 . The genetic groups are described in Figure 4 and Table 3. The genetic group, putative species (location) and population for the groups are as follows: 1 is Trapa sp. (U.S.) WP-VA, VCB-VA; 2 is Trapa sp. (U.S.) ML-VA; 3 is $T$. natans (U.S.) BR-MD1, CH-RI, CP-RI, IB-NY, SC-NY, TP-NY, MM-NY, SSB-NY, RC-NY, CDL-VT, CCD-NY, CMB-NY; 4 is T. natans (Japan) TEM-J, KO-J; 5 is T. japonica, T. natans var pumila (Japan) MIK-J1, IWA-J, ONO-J; 6 is T. incisa (Japan) NAK-J; 7 is Trapa sp. 2 (S. Africa) EM-KZN1.

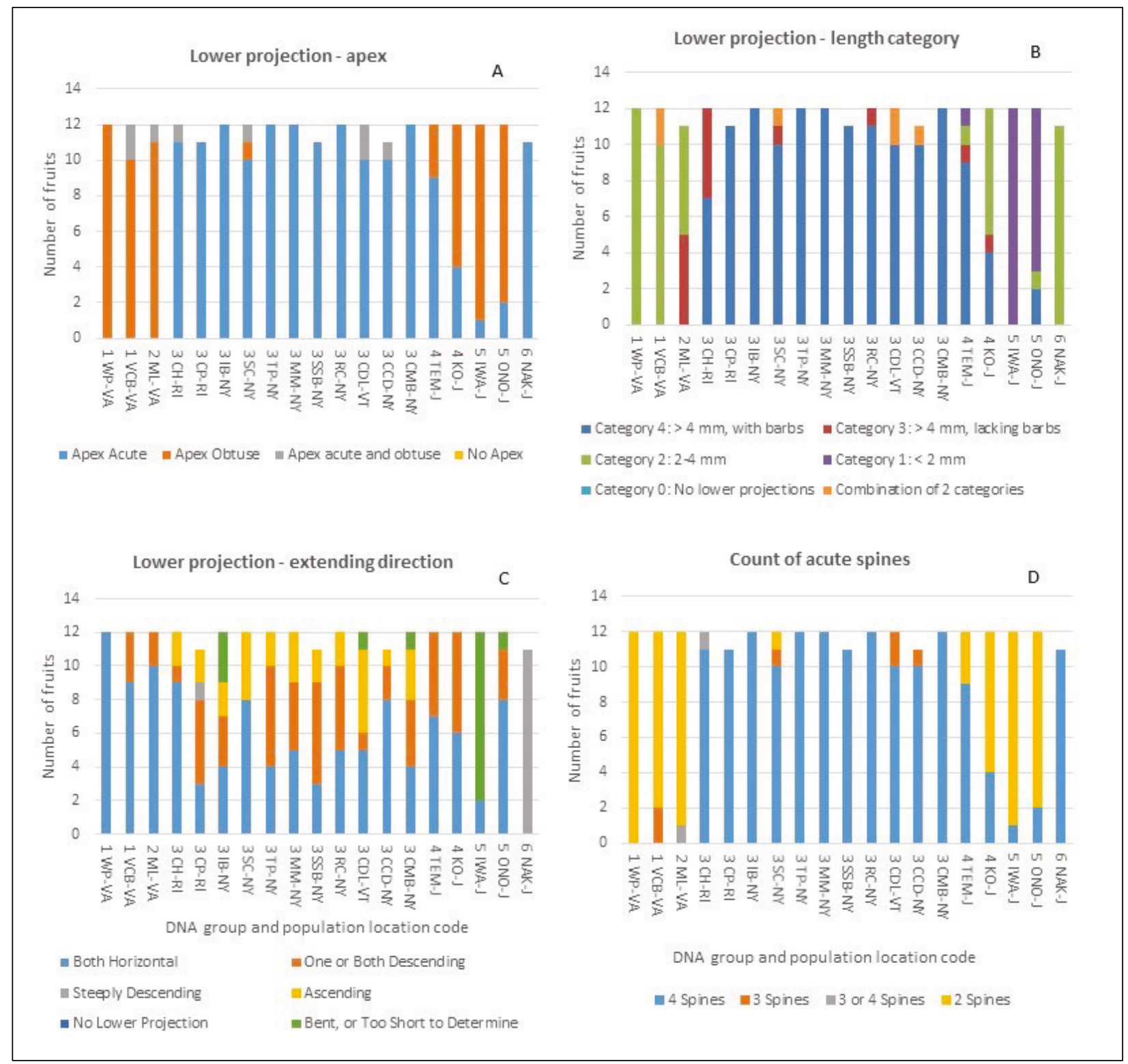

1/nsufficient number of quality fruits to summarize fruit morphology in the population.

Leaf and fruit characteristics: The mean total number of leaf teeth was largest for the U.S. T. natans population, SC-NY, and smallest for the Japanese T. incisa population, NAK-J (Figure 7 A). The mean fruit dry weight ranged from 0.5 to $3.0 \mathrm{~g}$, except in the NAK-J population, where it was $<0.25 \mathrm{~g}$ (Figure $7 \mathrm{~B}$ ). The Japanese population from NAK-J had the 
smallest $(8 \mathrm{~mm}$ ) and the $T$. natans TEM-J had the largest ( $45 \mathrm{~mm}$ ) mean width across the lower spines (Figure $7 \mathrm{C}$ ). The mean width across the upper spines ranged from $<20 \mathrm{~mm}$ at NAK-J to about $55 \mathrm{~mm}$ for the Japanese, T. natans populations, KO-J and TEM-J (Figure 7 D). Mean fruit height was between 15 and $25 \mathrm{~mm}$, except it was only $9 \mathrm{~mm}$ at the $T$. incisa population (Figure $7 \mathrm{E}$ ). While the fruit thickness of $T$. incisa was $4 \mathrm{~mm}$, the range was 8 to $14 \mathrm{~mm}$ at all other populations (Figure $7 \mathrm{~F}$ ). 
Figure 7. Mean \pm standard deviation for leaf and fruit characteristics. A, total number of teeth on leaf; $B$, Average dry weight of the fruits; C, Average width across upper spines; D, Average width across lower projections; E, Average height; F, Average thickness for populations in each of the genetic groups numbered 1 to 6 . The genetic groups are described in Figure 4 and Table 3. The genetic group, putative species (location) and population for the groups are as follows: 1 is Trapa sp. (U.S.) WP-VA, VCB-VA; 2 is Trapa sp. (U.S.) ML-VA; 3 is $T$. natans (U.S.) BR-MD1 ${ }^{1}$, CH-RI, CP-RI, IB-NY, SC-NY, TP-NY, MM-NY, SSB-NY, RC-NY, CDL-VT, CCD-NY, CMB-NY; 4 is T. natans (Japan) TEM-J, KO-J; 5 is T. japonica, T. natans var pumila (Japan) MIK-J1, IWA-J, ONO-J; 6 is $T$. incisa (Japan) NAK-J; 7 is Trapa sp. 2 (S. Africa) EM-KZN1.

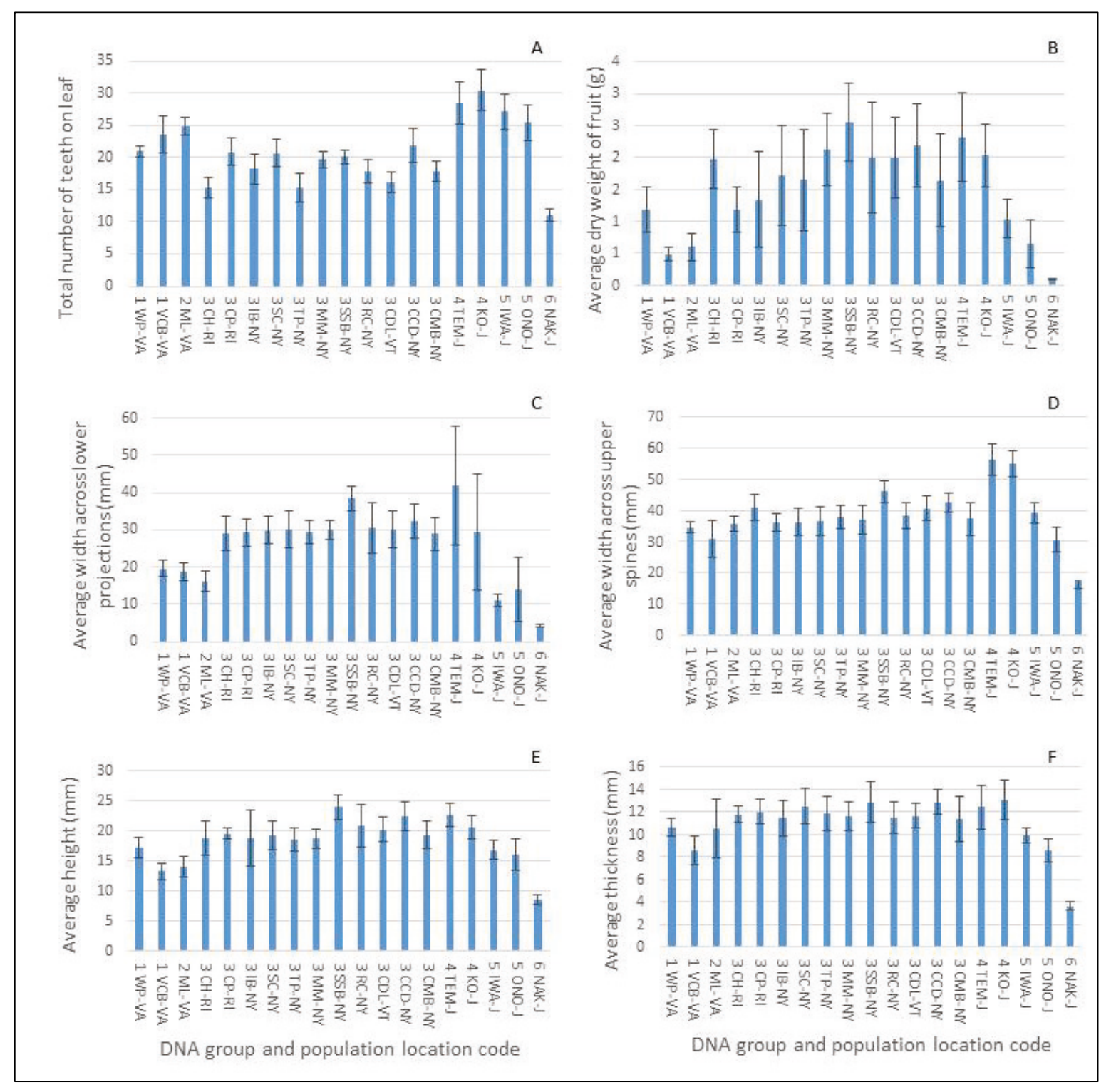

IInsufficient number of quality fruits to summarize fruit morphology in the population. 


\section{Conclusions}

The preliminary results presented for both the morphological and genetic data after one year of surveys indicate there are cryptic introductions of Trapa naturalized in the NE U.S. While efforts have been undertaken to clarify the taxonomy of Trapa (by the authors and other researchers), at this time, it is possible that more than one taxa is currently distributed and has naturalized in the U.S.

\subsection{Results}

The results of this study are preliminary and how these results impact management of Trapa in the U.S. remains unclear. For example, the use of herbicides (chemical control) is a commonly used strategy for management of water chestnut in the U.S. and has been limited to the use of two herbicides, 2,4-D (2,4-dicholorophenoxy acetic acid) and triclopyr [93,5,6-trichloro-2-pyridinyl)oxy] acetic acid (Hummel and Kiviat 2004; Poovey and Getsinger 2007; GLMRIS 2012). Further investigation into the effectiveness of these products (and potentially new products approved for use in aquatic systems) on these newly discovered cryptic introductions is warranted.

Biocontrol (an alternative method to physical and chemical control of Trapa) includes the use of co-evolved herbivores to reduce the competitive influence of Trapa. This is especially relevant for the current biocontrol paradigm of matching specific herbivores to plant taxa in a geographically specific way. Currently, two species of the genus Galerucella (leaf-beetle) (Coleoptera: Chrysomelidae) have been shown to impact Trapa natans (Pemberton 1999; Pemberton 2002). A native water lily leaf beetle, Galerucella nymphaeae, widely distributed in Europe and North America, can contribute to a reduction in Trapa plant performance (Ding and Blossey 2005). Feeding by G. nymphaeae has been reported on the Trapa sp. population observed at Gunston Cove on the Potomac River ${ }^{1}$, however, the long-term effects upon this population have not been evaluated. Galerucella birmanica is a promising potential biological control agent of T. natans (Ding et. al 2006), and may have the potential as a biocontrol agent for Trapa sp. Use of G. birmanica as a biocontrol for Trapa in the U.S. may reduce its photosynthetic ability and overall plant vigor leading

1 Rybicki, N. 2014. Personal communication with Nathan Harms via email. September 9. USGS and USACE ERDC. 
to decreased competitive ability, increasing the chances of native, more desirable submersed aquatic vegetation to compete for niche occupation (i.e., space, light, nutrients). It should be noted, however, that to date none of the insect agents found overseas and evaluated as biocontrol for water chestnut have been approved for release in the U.S. for the management of water chestnut.

\subsection{Future work}

The efforts of this work detail results from one year of morphological and genetics work for Trapa taxa in both its introduced and native ranges. Given the history and current problems associated with introduced water chestnut in the U.S., further investigation into the genetic and ecological characteristics of each distinct taxa are warranted, and will contribute to the knowledge base necessary for making decisions about managing this invasive plant. 


\section{References}

Britton, N. L., and A. Brown. 1970. An Illustrated Flora of the Northern United States and Canada, $2^{\text {nd }} e d$. New York: Dover Publications.

Carter, V., and N. Rybicki. 1994. Invasions and declines of submersed macrophytes in the tidal Potomac River and Estuary, the Currituck Sound-Back Bay system, and the Pamlico River Estuary. Lake and Reservoir Management 10(1):39-48. https://doi.org/10.1080/07438149409354171

Cook, C. D. K. 1990. Aquatic Plant Book. SPB Academic Publishing. The Hague, the Netherlands.

Caraco, N. F., and J. J. Cole. 2002. Contrasting impacts of a native and alien macrophyte on dissolved oxygen in a large river. Ecological Applications 12(5):1496-1509.

Crow, G. E., and C. B. Hellquist. 2000. Aquatic and wetland plants of north-eastern North America. Madison, WI: University of Wisconsin Press.

Ding, J., and B. Blossey. 2005. Impact of the native water lily leaf beetle, Galerucella nymphaeae (Coleoptera: Chrysomelidae), attacking introduced water chestnut, Trapa natans, in the Northeastern United States. Environmental Entomology 34(3):683-689. https://doi.org/10.1603/0046-225X-34.3.683

Ding, J., B. Blossey, Y. Du, and F. Zheng. 2006. Impact of Galerucella birmanica (Coleoptera: Chrysomelidae), on growth and seed production of Trapa natans. Biological Control 37(3):338-345. https://doi.org/10.1016/i.biocontrol.2005.12.003

Early Detection and Distribution Mapping System (EDDMapS). 2017. Early Detection and Distribution Mapping System. The University of Georgia - Center for Invasive Species and Ecosystem Health. Accessed 24 April 2017. http://www.eddmaps.org/

Graham, S. A., J. Hall, K. Sytsma, and S. Shi. 2005. Phylogenetic analysis of the Lythraceae based on four gene regions and morphology. International Journal of Plant Sciences 166(6):995-1017.

Great Lakes and Mississippi River Interbasin Study (GLMRIS) Team. 2012. Inventory of available controls for aquatic nuisance species of concern: Chicago Area Waterway System. Vicksburg, MS: U.S. Army Corps of Engineers. http://glmris.anl.gov/documents/docs/ANS_Control_Paper.pdf

Gwathmey, J. H. 1945. Potomac River cleared of floating islands. Maryland Conservationist 21:1-3.

Hardy, O. J., and X. Vekemans. 2002. SPAGeDi: A versatile computer program to analyse spatial genetic structure at the individual or population levels. Molecular Ecology Notes 2:618-620.

Hummel, M., and S. Findley. 2006. Effects of water chestnut (Trapa natans) beds on water chemistry in the tidal freshwater Hudson River. Hydrobiologia 559(1):169-181. 
Hummel, M., and E. Kiviat. 2004. Review of world literature on water chestnut with implications for management in North America. Journal of Aquatic Plant Management 42:17-27. http://www.apms.org/japm/vol42/v42p17.pdf

Integrated Taxonomic Information System (ITIS). 2015. Accessed 16 October 2015. http://www.itis.gov.

Kadono, Y. 1987. A preliminary study on the variation of Trapa in Japan. Acta Phytotaxonomica et Geobotanica 38:199-210 (In Japanese). http://doi.org/10.18942/bunruichiri.KJ00002992255.

Kadono, Y. 2018. A preliminary study of variation of Trapa in Japan (translated into English from the Japanese by V. Chintu Lai): U.S. Geological Survey Open-File Report 2018-1075. https://pubs.er.usgs.gov/publication/ofr20181075.

Kim, C., H. R. Na, and H-K. Choi. 2010. Molecular genotyping of Trapa bispinosa and T. japonica (Trapaceae) based on nuclear AP2 and chloroplast DNA trnL-F region. American Journal of Botany. 97:149-152. https://doi.org/10.3732/ajb.1000344

LaManche, K. 2007. The current state of aquatic invasive species in central New York. New York, NY: Central New York Regional Planning and Development Board. http://www.cnyrpdb.org/docs/environmental/InvasiveSpeciesReport.pdf

Les, D. and L. J. Mehrhoff. 1999. Introduction of nonindigenous aquatic vascular plants in southern New England: a historical perspective. Biological Invasions 1:281300 .

Li, X. L., X. R. Fan, H. J. Chu, W. Li, and Y. Y. Chen. 2017. Genetic delimitation and population structure of three Trapa taxa from the Yangtze River, China. Aquatic Botany 136:61-70. https://doi.org/10.1016/j.aquabot.2016.09.009.

Naylor, M. 2003. Water Chestnut (Trapa natans) in the Chesapeake Bay Watershed: A Regional Management Plan. Maryland Department of Natural Resources. http://www.anstaskforce.gov/Species\%20plans/Water\%20Chestnut\%20Mgt\%20Plan.pdf.

Peakall, R., and P. E. Smouse. 2006. GENALEX 6: Genetic analysis in Excel. Population genetic software for teaching and research. Molecular Ecology Notes 6(1):288295. https://doi.org/10.1111/j.1471-8286.2005.01155.x

Peakall, R., and P. E. Smouse. 2012. GenAlEx 6.5: Genetic analysis in Excel. Population genetic software for teaching and research - An update. Bioinformatics 28:25372539.

Pemberton, R. W. 1999. Natural enemies of Trapa spp. in northeast Asia and Europe. Biological Control 14(3):168-180. https://doi.org/10.1006/bcon.1998.0687

Pemberton, R. W. 2002. Water Chestnut. In Biological control of invasive plants in the eastern United States (FHTET-2002-04) ed. R. Van Dreiesche, S. Lyon, B. Blossey, M. Hoddle, and R. Reardon, 33-40. Morgantown, WV: USDA Forest Service.

Pfingsten, I. A., L. Cao, and L. Berent. 2017. Trapa natans L. Gainesville, FL: U.S. Geological Survey, Nonindigenous Aquatic Species Database. https://nas.er.usgs.gov/queries/FactSheet.aspx?SpeciesID=263 
Poovey, A. G. and K. D. Getsinger. 2007. Subsurface applications of triclopyr and 2, 4-D amine for control of water chestnut (Trapa natans L.). Journal of Aquatic Plant Management 45:63-66.

Rawls, C. 1964a. Aquatic plant nuisances. Interstate Commission on the Potomac River Basin 1:51-56.

Rawls, C. $1964 b$. Aquatic plant nuisances. Solomons, MD:University of Maryland, Chesapeake Biology Lab 64-15.

Takano A., and Y. Kadono. 2005. Allozyme variations and classification of Trapa(Trapaceae) in Japan. Aquatic Botany 83(2):108-118. https://doi: 10.1016/i.aquabot.2005.05.008

Thum, R. A., M. P. Zuellig, R. L. Johnson, M. L. Moody, and C. Vossbrinck. 2011. Molecular markers reconstruct the invasion history of variable leaf watermilfoil (Myriophyllum heterophyllum) and distinguish it from closely related species. Biological Invasions 13:1687-1709.

U.S. Department of Agriculture (USDA). 2016. Weed Risk Assessment for Trapa natans L. (Lythraceae) Water chestnut. Plant Protection and Quarantine, Animal and Plant Health Inspection Service, Raleigh, NC: USDA. https://www.aphis.usda.gov/aphis/home.

U.S. Geological Survey (USGS) Nonindigenous Aquatic Species Database (NASD), Gainesville, FL, and NOAA Great Lakes Aquatic Nonindigenous Species Information System (GLANSIS), Ann Arbor, MI. 2017. Trapa natans. Revision Date: 4/7/2016. https://nas.er.usgs.gov/queries/greatlakes/FactSheet.aspx?SpeciesID=263\&Potential=N\&Type $=0$. 


\section{Appendix A: Raw Data Used in Morphology and Genetic Analyses}

Table A-1. Principal Coordinates Analysis - X, Y data for Axis 1 and Axis 2 for Figure 4.

\begin{tabular}{|c|c|c|c|c|c|c|c|c|}
\hline $\begin{array}{l}\text { MSU } \\
\text { Sample } \\
\text { name }\end{array}$ & $\begin{array}{l}\text { USGS } \\
\text { sample } \\
\text { name }\end{array}$ & $\begin{array}{l}\text { Morphological } \\
\text { Species ID }\end{array}$ & Country & State & $\begin{array}{l}\text { Specific } \\
\text { location }\end{array}$ & County & $\begin{array}{l}\text { PCoA Axis } 1 \\
X\end{array}$ & $\begin{array}{l}\text { PCoA Axis } 2 \\
Y\end{array}$ \\
\hline TRA-0087 & NE-Test -87 & Trapa sp. & USA & VA & Waples Mill & Fairfax & 1.437 & -1.087 \\
\hline TRA-0087D & NE-Test -87 & Trapa sp. & USA & VA & Waples Mill & Fairfax & 1.370 & -0.969 \\
\hline TRA-0109 & SSB-NY1 & Trapa natans & USA & NY & $\begin{array}{l}\text { South Sodus } \\
\text { Bay }\end{array}$ & Wayne & -0.733 & -0.011 \\
\hline TRA-0114 & SSB-NY6 & Trapa natans & USA & NY & $\begin{array}{l}\text { South Sodus } \\
\text { Bay }\end{array}$ & Wayne & -0.789 & -0.185 \\
\hline TRA-0120 & SSB-NY12 & Trapa natans & USA & NY & $\begin{array}{l}\text { South Sodus } \\
\text { Bay }\end{array}$ & Wayne & -0.967 & -0.127 \\
\hline TRA-0126 & SSB-NY18 & Trapa natans & USA & NY & $\begin{array}{l}\text { South Sodus } \\
\text { Bay }\end{array}$ & Wayne & -0.949 & -0.139 \\
\hline TRA-0132 & SSB-NY24 & Trapa natans & USA & NY & $\begin{array}{l}\text { South Sodus } \\
\text { Bay }\end{array}$ & Wayne & -0.796 & -0.165 \\
\hline TRA-0132D & SSB-NY24 & Trapa natans & USA & NY & $\begin{array}{l}\text { South Sodus } \\
\text { Bay }\end{array}$ & Wayne & -0.843 & -0.176 \\
\hline TRA-0139 & RC-NY1 & Trapa natans & USA & NY & Red Creek & Wayne & -0.783 & -0.239 \\
\hline TRA-0144 & RC-NY6 & Trapa natans & USA & NY & Red Creek & Wayne & -0.861 & -0.025 \\
\hline TRA-0150 & RC-NY12 & Trapa natans & USA & NY & Red Creek & Wayne & -0.883 & -0.166 \\
\hline TRA-0156 & RC-NY18 & Trapa natans & USA & NY & Red Creek & Wayne & -0.925 & 0.061 \\
\hline TRA-0162 & RC-NY24 & Trapa natans & USA & NY & Red Creek & Wayne & -0.815 & -0.057 \\
\hline TRA-0168 & RC-NY30 & Trapa natans & USA & NY & Red Creek & Wayne & -1.030 & 0.046 \\
\hline TRA-0168D & RC-NY30 & Trapa natans & USA & NY & Red Creek & Wayne & -1.055 & 0.069 \\
\hline TRA-0169 & BR-MD1 & Trapa natans & USA & MD & Bird River & Baltimore & -0.842 & 0.017 \\
\hline TRA-0171 & BR-MD3 & Trapa natans & USA & MD & Bird River & Baltimore & -0.918 & -0.031 \\
\hline TRA-0173 & BR-MD5 & Trapa natans & USA & MD & Bird River & Baltimore & -0.939 & -0.061 \\
\hline TRA-0175 & BR-MD7 & Trapa natans & USA & MD & Bird River & Baltimore & -0.993 & -0.081 \\
\hline TRA-0177 & BR-MD9 & Trapa natans & USA & MD & Bird River & Baltimore & -0.838 & 0.006 \\
\hline TRA-0177D & BR-MD9 & Trapa natans & USA & MD & Bird River & Baltimore & -1.079 & 0.014 \\
\hline TRA-0179 & MM-NY1 & Trapa natans & USA & NY & $\begin{array}{l}\text { Montezuma } \\
\text { Marsh }\end{array}$ & Cayuga & -0.740 & -0.060 \\
\hline TRA-0209 & CDL-VT1 & Trapa natans & USA & VT & $\begin{array}{l}\text { Drowned } \\
\text { Lands, Lake } \\
\text { Champlain }\end{array}$ & Rutland & -1.080 & -0.015 \\
\hline TRA-0214 & CDL-VT6 & Trapa natans & USA & VT & $\begin{array}{l}\text { Drowned } \\
\text { Lands, Lake } \\
\text { Champlain }\end{array}$ & Rutland & -0.978 & -0.100 \\
\hline
\end{tabular}




\begin{tabular}{|c|c|c|c|c|c|c|c|c|}
\hline $\begin{array}{l}\text { MSU } \\
\text { Sample } \\
\text { name }\end{array}$ & $\begin{array}{l}\text { USGS } \\
\text { sample } \\
\text { name }\end{array}$ & $\begin{array}{l}\text { Morphological } \\
\text { Species ID }\end{array}$ & Country & State & $\begin{array}{l}\text { Specific } \\
\text { location }\end{array}$ & County & $\begin{array}{l}\text { PCoA Axis } 1 \\
X\end{array}$ & $\begin{array}{l}\text { PCoA Axis } 2 \\
Y\end{array}$ \\
\hline TRA-0220 & CDL-VT12 & Trapa natans & USA & VT & $\begin{array}{l}\text { Drowned } \\
\text { Lands, Lake } \\
\text { Champlain }\end{array}$ & Rutland & -0.917 & -0.038 \\
\hline TRA-0226 & CDL-VT18 & Trapa natans & USA & VT & $\begin{array}{l}\text { Drowned } \\
\text { Lands, Lake } \\
\text { Champlain }\end{array}$ & Rutland & -0.852 & -0.003 \\
\hline TRA-0232 & CDL-VT24 & Trapa natans & USA & VT & $\begin{array}{l}\text { Drowned } \\
\text { Lands, Lake } \\
\text { Champlain }\end{array}$ & Rutland & -1.039 & -0.023 \\
\hline TRA-0238 & CDL-VT30 & Trapa natans & USA & VT & $\begin{array}{l}\text { Drowned } \\
\text { Lands, Lake } \\
\text { Champlain }\end{array}$ & Rutland & -1.036 & -0.152 \\
\hline TRA-0238D & CDL-VT30 & Trapa natans & USA & VT & $\begin{array}{l}\text { Drowned } \\
\text { Lands, Lake } \\
\text { Champlain }\end{array}$ & Rutland & -0.999 & 0.019 \\
\hline TRA-0239 & CMB-NY1 & Trapa natans & USA & NY & $\begin{array}{l}\text { Mill Bay, Lake } \\
\text { Champlain }\end{array}$ & Warren & -0.943 & 0.015 \\
\hline TRA-0244 & CMB-NY6 & Trapa natans & USA & NY & $\begin{array}{l}\text { Mill Bay, Lake } \\
\text { Champlain }\end{array}$ & Warren & -0.703 & -0.123 \\
\hline TRA-0250 & CMB-NY12 & Trapa natans & USA & NY & $\begin{array}{l}\text { Mill Bay, Lake } \\
\text { Champlain }\end{array}$ & Warren & -0.594 & -0.098 \\
\hline TRA-0256 & CMB-NY18 & Trapa natans & USA & NY & $\begin{array}{l}\text { Mill Bay, Lake } \\
\text { Champlain }\end{array}$ & Warren & -0.974 & 0.056 \\
\hline TRA-0262 & CMB-NY24 & Trapa natans & USA & NY & $\begin{array}{l}\text { Mill Bay, Lake } \\
\text { Champlain }\end{array}$ & Warren & -1.053 & 0.024 \\
\hline TRA-0262D & CMB-NY24 & Trapa natans & USA & NY & $\begin{array}{l}\text { Mill Bay, Lake } \\
\text { Champlain }\end{array}$ & Warren & -1.061 & -0.010 \\
\hline TRA-0269 & CCD-NY1 & Trapa natans & USA & NY & $\begin{array}{l}\text { Chubbs Dock, } \\
\text { Lake } \\
\text { Champlain }\end{array}$ & Washington & -0.895 & -0.153 \\
\hline TRA-0274 & CCD-NY6 & Trapa natans & USA & NY & $\begin{array}{l}\text { Chubbs Dock, } \\
\text { Lake } \\
\text { Champlain }\end{array}$ & Washington & -1.035 & 0.045 \\
\hline TRA-0292 & CCD-NY24 & Trapa natans & USA & NY & $\begin{array}{l}\text { Chubbs Dock, } \\
\text { Lake } \\
\text { Champlain }\end{array}$ & Washington & -0.849 & 0.008 \\
\hline TRA-0299 & TP-NY1 & Trapa natans & USA & NY & $\begin{array}{l}\text { Tivoli Lake } \\
\text { Park }\end{array}$ & Albany & -1.002 & 0.016 \\
\hline TRA-0304 & TP-NY6 & Trapa natans & USA & NY & $\begin{array}{l}\text { Tivoli Lake } \\
\text { Park }\end{array}$ & Albany & -0.886 & 0.076 \\
\hline TRA-0310 & TP-NY12 & Trapa natans & USA & NY & $\begin{array}{l}\text { Tivoli Lake } \\
\text { Park }\end{array}$ & Albany & -0.846 & 0.005 \\
\hline TRA-0316 & TP-NY18 & Trapa natans & USA & NY & $\begin{array}{l}\text { Tivoli Lake } \\
\text { Park }\end{array}$ & Albany & -0.942 & 0.003 \\
\hline
\end{tabular}




\begin{tabular}{|c|c|c|c|c|c|c|c|c|}
\hline $\begin{array}{l}\text { MSU } \\
\text { Sample } \\
\text { name }\end{array}$ & $\begin{array}{l}\text { USGS } \\
\text { sample } \\
\text { name }\end{array}$ & $\begin{array}{l}\text { Morphological } \\
\text { Species ID }\end{array}$ & Country & State & $\begin{array}{l}\text { Specific } \\
\text { location }\end{array}$ & County & $\begin{array}{l}\text { PCoA Axis } 1 \\
X\end{array}$ & $\begin{array}{l}\text { PCoA Axis } 2 \\
Y\end{array}$ \\
\hline TRA-0322 & TP-NY24 & Trapa natans & USA & NY & $\begin{array}{l}\text { Tivoli Lake } \\
\text { Park }\end{array}$ & Albany & -1.036 & -0.112 \\
\hline TRA-0322D & TP-NY24 & Trapa natans & USA & NY & $\begin{array}{l}\text { Tivoli Lake } \\
\text { Park }\end{array}$ & Albany & -1.059 & -0.038 \\
\hline TRA-0329 & IB-NY1 & Trapa natans & USA & NY & Inbocht Bay & Greene & -0.992 & -0.124 \\
\hline TRA-0334 & IB-NY6 & Trapa natans & USA & NY & Inbocht Bay & Greene & -1.040 & -0.078 \\
\hline TRA-0340 & IB-NY12 & Trapa natans & USA & NY & Inbocht Bay & Greene & -1.122 & 0.016 \\
\hline TRA-0346 & IB-NY18 & Trapa natans & USA & NY & Inbocht Bay & Greene & -1.037 & 0.084 \\
\hline TRA-0352 & IB-NY24 & Trapa natans & USA & NY & Inbocht Bay & Greene & -0.954 & 0.092 \\
\hline TRA-0352D & IB-NY24 & Trapa natans & USA & NY & Inbocht Bay & Greene & -0.960 & 0.098 \\
\hline TRA-0359 & SC-NY1 & Trapa natans & USA & NY & $\begin{array}{l}\text { Stockport } \\
\text { Creek }\end{array}$ & Columbia & -0.635 & 0.051 \\
\hline TRA-0364 & SC-NY6 & Trapa natans & USA & NY & $\begin{array}{l}\text { Stockport } \\
\text { Creek }\end{array}$ & Columbia & -0.906 & 0.008 \\
\hline TRA-0370 & SC-NY12 & Trapa natans & USA & NY & $\begin{array}{l}\text { Stockport } \\
\text { Creek }\end{array}$ & Columbia & -0.289 & -0.025 \\
\hline TRA-0376 & SC-NY18 & Trapa natans & USA & NY & $\begin{array}{l}\text { Stockport } \\
\text { Creek }\end{array}$ & Columbia & -0.997 & 0.015 \\
\hline TRA-0388D & SC-NY30 & Trapa natans & USA & NY & $\begin{array}{l}\text { Stockport } \\
\text { Creek }\end{array}$ & Columbia & -0.992 & 0.088 \\
\hline TRA-0400 & ML-VA13 & Trapa sp. & USA & VA & Myrtle Leaf dr. & Fairfax & -0.054 & -0.434 \\
\hline TRA-0406 & ML-VA19 & Trapa sp. & USA & VA & Myrtle Leaf dr. & Fairfax & -0.181 & -0.405 \\
\hline TRA-0412 & ML-VA25 & Trapa sp. & USA & VA & Myrtle Leaf dr. & Fairfax & 0.056 & -0.740 \\
\hline TRA-0412D & ML-VA25 & Trapa sp. & USA & VA & Myrtle Leaf dr. & Fairfax & -0.003 & -0.749 \\
\hline TRA-0421 & CP-RI3 & Trapa natans & USA & RI & Central Pond & Providence & -0.730 & -0.014 \\
\hline TRA-0426 & CP-RI8 & Trapa natans & USA & RI & Central Pond & Providence & -0.866 & -0.043 \\
\hline TRA-0432 & CP-RI14 & Trapa natans & USA & RI & Central Pond & Providence & -0.973 & -0.040 \\
\hline TRA-0438 & CP-RI20 & Trapa natans & USA & RI & Central Pond & Providence & -0.937 & -0.097 \\
\hline TRA-0444 & CP-RI26 & Trapa natans & USA & RI & Central Pond & Providence & -1.082 & 0.033 \\
\hline TRA-0444D & CP-RI26 & Trapa natans & USA & RI & Central Pond & Providence & -1.000 & -0.067 \\
\hline TRA-0450 & CP-RI32 & Trapa natans & USA & RI & Central Pond & Providence & -0.688 & 0.021 \\
\hline TRA-0451 & $\mathrm{CH}-\mathrm{RI} 1$ & Trapa natans & USA & RI & $\begin{array}{l}\text { Chapman } \\
\text { Pond }\end{array}$ & Washington & -0.952 & 0.050 \\
\hline TRA-0456 & CH-RI6 & Trapa natans & USA & RI & $\begin{array}{l}\text { Chapman } \\
\text { Pond }\end{array}$ & Washington & -1.063 & 0.029 \\
\hline TRA-0462 & CH-RI12 & Trapa natans & USA & RI & $\begin{array}{l}\text { Chapman } \\
\text { Pond }\end{array}$ & Washington & -1.063 & 0.048 \\
\hline TRA-0468 & CH-RI18 & Trapa natans & USA & RI & $\begin{array}{l}\text { Chapman } \\
\text { Pond }\end{array}$ & Washington & -1.035 & 0.005 \\
\hline
\end{tabular}




\begin{tabular}{|c|c|c|c|c|c|c|c|c|}
\hline $\begin{array}{l}\text { MSU } \\
\text { Sample } \\
\text { name }\end{array}$ & $\begin{array}{l}\text { USGS } \\
\text { sample } \\
\text { name }\end{array}$ & $\begin{array}{l}\text { Morphological } \\
\text { Species ID }\end{array}$ & Country & State & $\begin{array}{l}\text { Specific } \\
\text { location }\end{array}$ & County & $\begin{array}{l}\text { PCoA Axis } 1 \\
X\end{array}$ & $\begin{array}{l}\text { PCoA Axis } 2 \\
Y\end{array}$ \\
\hline TRA-0474 & $\mathrm{CH}-\mathrm{RI} 24$ & Trapa natans & USA & $\mathrm{RI}$ & $\begin{array}{l}\text { Chapman } \\
\text { Pond }\end{array}$ & Washington & -0.861 & -0.041 \\
\hline TRA-0480 & $\mathrm{CH}-\mathrm{RI} 30$ & Trapa natans & USA & $\mathrm{RI}$ & $\begin{array}{l}\text { Chapman } \\
\text { Pond }\end{array}$ & Washington & -0.909 & -0.092 \\
\hline TRA-0480D & $\mathrm{CH}-\mathrm{RI} 30$ & Trapa natans & USA & $\mathrm{RI}$ & $\begin{array}{l}\text { Chapman } \\
\text { Pond }\end{array}$ & Washington & -0.644 & -0.132 \\
\hline TRA-0483 & EM-KZN1 & Trapa sp. & $\begin{array}{l}\text { South } \\
\text { Africa }\end{array}$ & KZN & Empangeni & $\begin{array}{l}\text { KwaZulu- } \\
\text { Natal }\end{array}$ & -0.003 & 0.568 \\
\hline TRA-0488 & EM-KZN6 & Trapa sp. & $\begin{array}{l}\text { South } \\
\text { Africa }\end{array}$ & KZN & Empangeni & $\begin{array}{l}\text { KwaZulu- } \\
\text { Natal }\end{array}$ & -0.056 & 0.618 \\
\hline TRA-0494 & EM-KZN12 & Trapa sp. & $\begin{array}{l}\text { South } \\
\text { Africa }\end{array}$ & KZN & Empangeni & $\begin{array}{l}\text { KwaZulu- } \\
\text { Natal }\end{array}$ & -0.123 & 0.664 \\
\hline TRA-0500 & EM-KZN18 & Trapa sp. & $\begin{array}{l}\text { South } \\
\text { Africa }\end{array}$ & KZN & Empangeni & $\begin{array}{l}\text { KwaZulu- } \\
\text { Natal }\end{array}$ & 0.009 & 0.675 \\
\hline TRA-0500D & EM-KZN18 & Trapa sp. & $\begin{array}{l}\text { South } \\
\text { Africa }\end{array}$ & KZN & Empangeni & $\begin{array}{l}\text { KwaZulu- } \\
\text { Natal }\end{array}$ & -0.147 & 0.694 \\
\hline TRA-0502 & EM-KZN20 & Trapa sp. & $\begin{array}{l}\text { South } \\
\text { Africa }\end{array}$ & KZN & Empangeni & $\begin{array}{l}\text { KwaZulu- } \\
\text { Natal }\end{array}$ & -0.176 & 0.613 \\
\hline TRA-0502D & EM-KZN20 & Trapa sp. & $\begin{array}{l}\text { South } \\
\text { Africa }\end{array}$ & KZN & Empangeni & $\begin{array}{l}\text { KwaZulu- } \\
\text { Natal }\end{array}$ & -0.193 & 0.569 \\
\hline TRA-0503 & WP-VA1 & Trapa sp. & USA & VA & Waples & Fairfax & 1.399 & -1.271 \\
\hline TRA-0509 & WP-VA7 & Trapa sp. & USA & VA & Waples & Fairfax & 1.426 & -1.261 \\
\hline TRA-0515 & WP-VA13 & Trapa sp. & USA & VA & Waples & Fairfax & 1.446 & -1.187 \\
\hline TRA-0521 & WP-VA19 & Trapa sp. & USA & VA & Waples & Fairfax & 1.439 & -1.263 \\
\hline TRA-0527 & WP-VA25 & Trapa sp. & USA & VA & Waples & Fairfax & 1.433 & -1.309 \\
\hline TRA-0527D & WP-VA25 & Trapa sp. & USA & VA & Waples & Fairfax & 1.393 & -1.294 \\
\hline TRA-0533 & VCB-VA2 & Trapa sp. & USA & VA & Nutley & Fairfax & 1.449 & -1.200 \\
\hline TRA-0539 & VCB-VA8 & Trapa sp. & USA & VA & Nutley & Fairfax & 1.285 & -1.234 \\
\hline TRA-0545 & VCB-VA14 & Trapa sp. & USA & VA & Nutley & Fairfax & 1.396 & -1.264 \\
\hline TRA-0550 & VCB-VA19 & Trapa sp. & USA & VA & Nutley & Fairfax & 1.370 & -1.186 \\
\hline TRA-0556 & VCB-VA25 & Trapa sp. & USA & VA & Nutley & Fairfax & 1.337 & -1.243 \\
\hline TRA-0556D & VCB-VA25 & Trapa sp. & USA & VA & Nutley & Fairfax & 1.395 & -1.223 \\
\hline TRA-0563 & ONO-J1 & Trapa japonica & Japan & $\begin{array}{l}\text { Hyogo } \\
\text { Prefecture }\end{array}$ & $\begin{array}{l}\text { Irrigation pond } \\
\text { in Kashiyama- } \\
\text { cho }\end{array}$ & Ono City & 1.568 & 0.468 \\
\hline TRA-0569 & ONO-J7 & Trapa japonica & Japan & $\begin{array}{l}\text { Hyogo } \\
\text { Prefecture }\end{array}$ & $\begin{array}{l}\text { Irrigation pond } \\
\text { in Kashiyama- } \\
\text { cho }\end{array}$ & Ono City & 1.584 & 0.513 \\
\hline TRA-0575 & ONO-J13 & Trapa japonica & Japan & $\begin{array}{l}\text { Hyogo } \\
\text { Prefecture }\end{array}$ & $\begin{array}{l}\text { Irrigation pond } \\
\text { in Kashiyama- } \\
\text { cho }\end{array}$ & Ono City & 1.410 & 0.539 \\
\hline
\end{tabular}




\begin{tabular}{|c|c|c|c|c|c|c|c|c|}
\hline $\begin{array}{l}\text { MSU } \\
\text { Sample } \\
\text { name }\end{array}$ & $\begin{array}{l}\text { USGS } \\
\text { sample } \\
\text { name }\end{array}$ & $\begin{array}{l}\text { Morphological } \\
\text { Species ID }\end{array}$ & Country & State & $\begin{array}{l}\text { Specific } \\
\text { location }\end{array}$ & County & $\begin{array}{l}\text { PCoA Axis } 1 \\
X\end{array}$ & $\begin{array}{l}\text { PCoA Axis } 2 \\
Y\end{array}$ \\
\hline TRA-0581 & ONO-J19 & $\begin{array}{l}\text { Trapa natans } \\
\text { var. pumila }\end{array}$ & Japan & $\begin{array}{l}\text { Hyogo } \\
\text { Prefecture }\end{array}$ & $\begin{array}{l}\text { Irrigation pond } \\
\text { in Kashiyama- } \\
\text { cho }\end{array}$ & Ono City & 1.472 & 0.471 \\
\hline TRA-0587 & ONO-J25 & Trapa japonica & Japan & $\begin{array}{l}\text { Hyogo } \\
\text { Prefecture }\end{array}$ & $\begin{array}{l}\text { Irrigation pond } \\
\text { in Kashiyama- } \\
\text { cho }\end{array}$ & Ono City & 1.630 & 0.712 \\
\hline TRA-0587D & ONO-J25 & Trapa japonica & Japan & $\begin{array}{l}\text { Hyogo } \\
\text { Prefecture }\end{array}$ & $\begin{array}{l}\text { Irrigation pond } \\
\text { in Kashiyama- } \\
\text { cho }\end{array}$ & Ono City & 1.617 & 0.616 \\
\hline TRA-0593 & IWA-J1 & Trapa japonica & Japan & $\begin{array}{l}\text { Hyogo } \\
\text { Prefecture }\end{array}$ & $\begin{array}{l}\text { Oh-ike Pond in } \\
\text { Iwaoka-cho }\end{array}$ & Kobe City & 1.541 & 0.577 \\
\hline TRA-0599 & IWA-J7 & Trapa japonica & Japan & $\begin{array}{l}\text { Hyogo } \\
\text { Prefecture }\end{array}$ & $\begin{array}{l}\text { Oh-ike Pond in } \\
\text { Iwaoka-cho }\end{array}$ & Kobe City & 1.548 & 0.630 \\
\hline TRA-0605 & IWA-J13 & Trapa japonica & Japan & $\begin{array}{l}\text { Hyogo } \\
\text { Prefecture }\end{array}$ & $\begin{array}{l}\text { Oh-ike Pond in } \\
\text { Iwaoka-cho }\end{array}$ & Kobe City & 1.632 & 0.672 \\
\hline TRA-0611 & IWA-J19 & Trapa japonica & Japan & $\begin{array}{l}\text { Hyogo } \\
\text { Prefecture }\end{array}$ & $\begin{array}{l}\text { Oh-ike Pond in } \\
\text { Iwaoka-cho }\end{array}$ & Kobe City & 1.476 & 0.710 \\
\hline TRA-0617 & IWA-J25 & Trapa japonica & Japan & $\begin{array}{l}\text { Hyogo } \\
\text { Prefecture }\end{array}$ & $\begin{array}{l}\text { Oh-ike Pond in } \\
\text { Iwaoka-cho }\end{array}$ & Kobe City & 1.543 & 0.358 \\
\hline TRA-0617D & IWA-J25 & Trapa japonica & Japan & $\begin{array}{l}\text { Hyogo } \\
\text { Prefecture }\end{array}$ & $\begin{array}{l}\text { Oh-ike Pond in } \\
\text { Iwaoka-cho }\end{array}$ & Kobe City & 1.557 & 0.350 \\
\hline TRA-0623 & MIK-J1 & $\begin{array}{l}\text { Trapa natans } \\
\text { var. pumila }\end{array}$ & Japan & $\begin{array}{l}\text { Fukui } \\
\text { Prefecture }\end{array}$ & $\begin{array}{l}\text { Lake Mikata } \\
\text { in Wakasa-cho }\end{array}$ & $\begin{array}{l}\text { Mikata } \\
\text { District }\end{array}$ & 1.666 & 0.641 \\
\hline TRA-0629 & MIK-J7 & Trapa japonica & Japan & $\begin{array}{l}\text { Fukui } \\
\text { Prefecture }\end{array}$ & $\begin{array}{l}\text { Lake Mikata } \\
\text { in Wakasa-cho }\end{array}$ & $\begin{array}{l}\text { Mikata } \\
\text { District }\end{array}$ & 1.515 & 0.730 \\
\hline TRA-0635 & MIK-J13 & $\begin{array}{l}\text { Trapa natans } \\
\text { var. pumila }\end{array}$ & Japan & $\begin{array}{l}\text { Fukui } \\
\text { Prefecture }\end{array}$ & $\begin{array}{l}\text { Lake Mikata } \\
\text { in Wakasa-cho }\end{array}$ & $\begin{array}{l}\text { Mikata } \\
\text { District }\end{array}$ & 1.593 & 0.688 \\
\hline TRA-0641 & MIK-J19 & Trapa japonica & Japan & $\begin{array}{l}\text { Fukui } \\
\text { Prefecture }\end{array}$ & $\begin{array}{l}\text { Lake Mikata } \\
\text { in Wakasa-cho }\end{array}$ & $\begin{array}{l}\text { Mikata } \\
\text { District }\end{array}$ & 1.592 & 0.687 \\
\hline TRA-0647 & MIK-J25 & $\begin{array}{l}\text { Trapa natans } \\
\text { var. pumila }\end{array}$ & Japan & $\begin{array}{l}\text { Fukui } \\
\text { Prefecture }\end{array}$ & $\begin{array}{l}\text { Lake Mikata } \\
\text { in Wakasa-cho }\end{array}$ & $\begin{array}{l}\text { Mikata } \\
\text { District }\end{array}$ & 1.469 & 0.653 \\
\hline TRA-0647D & MIK-J25 & $\begin{array}{l}\text { Trapa natans } \\
\text { var. pumila }\end{array}$ & Japan & $\begin{array}{l}\text { Fukui } \\
\text { Prefecture }\end{array}$ & $\begin{array}{l}\text { Lake Mikata } \\
\text { in Wakasa-cho }\end{array}$ & $\begin{array}{l}\text { Mikata } \\
\text { District }\end{array}$ & 1.454 & 0.638 \\
\hline TRA-0653 & KO-J1 & Trapa natans & Japan & $\begin{array}{l}\text { Hyogo } \\
\text { Prefecture }\end{array}$ & $\begin{array}{l}\text { Ohtoribami-ike } \\
\text { Pond in } \\
\text { Kande-cho }\end{array}$ & Kobe City & 0.601 & 0.057 \\
\hline TRA-0659 & KO-J7 & Trapa natans & Japan & $\begin{array}{l}\text { Hyogo } \\
\text { Prefecture }\end{array}$ & $\begin{array}{l}\text { Ohtoribami-ike } \\
\text { Pond in } \\
\text { Kande-cho }\end{array}$ & Kobe City & 0.957 & 0.464 \\
\hline TRA-0671 & KO-J19 & Trapa natans & Japan & $\begin{array}{l}\text { Hyogo } \\
\text { Prefecture }\end{array}$ & $\begin{array}{l}\text { Ohtoribami-ike } \\
\text { Pond in } \\
\text { Kande-cho }\end{array}$ & Kobe City & 0.786 & 0.143 \\
\hline TRA-0677 & KO-J25 & Trapa natans & Japan & $\begin{array}{l}\text { Hyogo } \\
\text { Prefecture }\end{array}$ & $\begin{array}{l}\text { Ohtoribami-ike } \\
\text { Pond in } \\
\text { Kande-cho }\end{array}$ & Kobe City & 0.934 & 0.613 \\
\hline
\end{tabular}




\begin{tabular}{|c|c|c|c|c|c|c|c|c|}
\hline $\begin{array}{l}\text { MSU } \\
\text { Sample } \\
\text { name }\end{array}$ & $\begin{array}{l}\text { USGS } \\
\text { sample } \\
\text { name }\end{array}$ & $\begin{array}{l}\text { Morphological } \\
\text { Species ID }\end{array}$ & Country & State & $\begin{array}{l}\text { Specific } \\
\text { location }\end{array}$ & County & $\begin{array}{l}\text { PCoA Axis } 1 \\
\mathrm{X}\end{array}$ & $\begin{array}{l}\text { PCoA Axis } 2 \\
Y\end{array}$ \\
\hline TRA-0677D & KO-J25 & Trapa natans & Japan & $\begin{array}{l}\text { Hyogo } \\
\text { Prefecture }\end{array}$ & $\begin{array}{l}\text { Ohtoribami-ike } \\
\text { Pond in } \\
\text { Kande-cho }\end{array}$ & Kobe City & 0.967 & 0.515 \\
\hline TRA-0683 & TEM-J1 & Trapa natans & Japan & \begin{tabular}{|l|} 
Hyogo \\
Prefecture
\end{tabular} & $\begin{array}{l}\text { Temma-Oh-ike } \\
\text { in Inami-cho }\end{array}$ & $\begin{array}{l}\text { Kako } \\
\text { District }\end{array}$ & 0.809 & 0.352 \\
\hline TRA-0689 & TEM-J7 & Trapa natans & Japan & $\begin{array}{l}\text { Hyogo } \\
\text { Prefecture }\end{array}$ & $\begin{array}{l}\text { Temma-Oh-ike } \\
\text { in Inami-cho }\end{array}$ & $\begin{array}{l}\text { Kako } \\
\text { District }\end{array}$ & 0.786 & 0.250 \\
\hline TRA-0695 & TEM-J13 & Trapa natans & Japan & \begin{tabular}{|l} 
Hyogo \\
Prefecture
\end{tabular} & $\begin{array}{l}\text { Temma-Oh-ike } \\
\text { in Inami-cho }\end{array}$ & $\begin{array}{l}\text { Kako } \\
\text { District }\end{array}$ & 0.831 & 0.505 \\
\hline TRA-0701 & TEM-J19 & Trapa natans & Japan & $\begin{array}{l}\text { Hyogo } \\
\text { Prefecture }\end{array}$ & $\begin{array}{l}\text { Temma-Oh-ike } \\
\text { in Inami-cho }\end{array}$ & $\begin{array}{l}\text { Kako } \\
\text { District }\end{array}$ & 0.898 & 0.455 \\
\hline TRA-0707 & TEM-J25 & Trapa natans & Japan & $\begin{array}{l}\text { Hyogo } \\
\text { Prefecture }\end{array}$ & $\begin{array}{l}\text { Temma-Oh-ike } \\
\text { in Inami-cho }\end{array}$ & $\begin{array}{l}\text { Kako } \\
\text { District }\end{array}$ & 1.026 & 0.465 \\
\hline TRA-0707D & TEM-J25 & Trapa natans & Japan & $\begin{array}{l}\text { Hyogo } \\
\text { Prefecture }\end{array}$ & $\begin{array}{l}\text { Temma-Oh-ike } \\
\text { in Inami-cho }\end{array}$ & $\begin{array}{l}\text { Kako } \\
\text { District }\end{array}$ & 0.991 & 0.413 \\
\hline TRA-0713 & NAK-J1 & Trapa incisa & Japan & $\begin{array}{l}\text { Fukui } \\
\text { Prefecture }\end{array}$ & $\begin{array}{l}\text { Nakaikemi } \\
\text { Marsh }\end{array}$ & Tsuruga City & 1.070 & 0.464 \\
\hline TRA-0719 & NAK-J7 & Trapa incisa & Japan & $\begin{array}{l}\text { Fukui } \\
\text { Prefecture }\end{array}$ & $\begin{array}{l}\text { Nakaikemi } \\
\text { Marsh }\end{array}$ & Tsuruga City & 1.009 & 0.455 \\
\hline TRA-0725 & NAK-J17 & Trapa incisa & Japan & $\begin{array}{l}\text { Fukui } \\
\text { Prefecture }\end{array}$ & $\begin{array}{l}\text { Nakaikemi } \\
\text { Marsh }\end{array}$ & Tsuruga City & 1.027 & 0.414 \\
\hline TRA-0731 & NAK-J23 & Trapa incisa & Japan & $\begin{array}{l}\text { Fukui } \\
\text { Prefecture }\end{array}$ & $\begin{array}{l}\text { Nakaikemi } \\
\text { Marsh }\end{array}$ & Tsuruga City & 0.997 & 0.402 \\
\hline TRA-0731D & NAK-J23 & Trapa incisa & Japan & $\begin{array}{l}\text { Fukui } \\
\text { Prefecture }\end{array}$ & $\begin{array}{l}\text { Nakaikemi } \\
\text { Marsh }\end{array}$ & Tsuruga City & 1.027 & 0.323 \\
\hline
\end{tabular}

Table A-2a. Summary of populations sampled and their respective genetic groups, species, latitude, and longitude.

\begin{tabular}{|l|l|l|l|l|}
\hline Population code & $\begin{array}{l}\text { Genetic } \\
\text { group }\end{array}$ & Putative species & Latitude & Longitude \\
\hline 1 WP-VA & 1 & sp. & 38.87362 & -77.33995 \\
\hline 1 VCB-VA & 1 & sp. & 38.88058 & -77.26836 \\
\hline 2 ML-VA & 2 & sp. & 38.84248 & -77.39606 \\
\hline 3 BR-MD & 3 & natans & 39.37445 & -76.38227 \\
\hline 3 CH-RI & 3 & natans & 41.38061 & -71.79996 \\
\hline 3 CP-RI & 3 & natans & 41.86245 & -71.33634 \\
\hline 3 IB-NY & 3 & natans & 42.16271 & -73.89591 \\
\hline 3 SC-NY & 3 & natans & 42.30986 & -73.77333 \\
\hline 3 TP-NY & 3 & natans & 42.67101 & -73.76099 \\
\hline
\end{tabular}




\begin{tabular}{|l|l|l|l|l|}
\hline 3 MM-NY & 3 & natans & 43.08148 & -76.64871 \\
\hline 3 SSB-NY & 3 & natans & 43.21568 & -76.92658 \\
\hline 3 RC-NY & 3 & natans & 43.30000 & -76.78114 \\
\hline 3 CDL-VT & 3 & natans & 43.61807 & -72.41948 \\
\hline 3 CCD-NY & 3 & natans & 43.64984 & -73.42343 \\
\hline 3 CMB-NY & 3 & natans & 43.74027 & -73.37408 \\
\hline 4 TEM-J & 4 & natans & 34.73361 & 134.90861 \\
\hline 4 KO-J & 4 & natans & 34.74000 & 134.98389 \\
\hline 5 IWA-J & 5 & japonica & 34.68139 & 134.97111 \\
\hline 5 ONO-J & 5 & japonica and natans var. pumila & 34.81694 & 134.95694 \\
\hline 5 MIK-J & 5 & japonica and natans var. pumila & 35.55972 & 135.89250 \\
\hline 6 NAK-J & 6 & incisa & 35.65806 & 136.09000 \\
\hline 7 EM-KZN & 7 & sp. 2 & -28.80938 & 31.89342 \\
\hline
\end{tabular}


Table A-2b. Summary of selected morphological parameters by population and genetic group $(\mathrm{N}=$ number of samples, $\mathrm{nd}=$ no data).

\begin{tabular}{|c|c|c|c|c|c|c|c|c|c|c|c|c|c|}
\hline 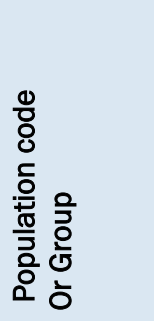 & 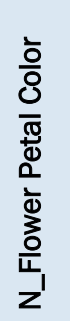 & 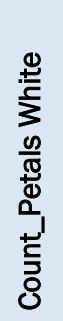 & 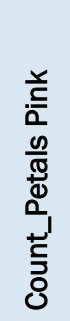 & 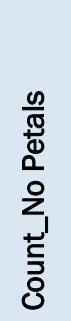 & 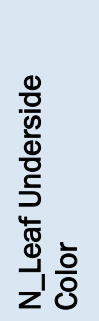 & 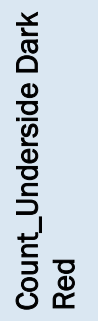 & 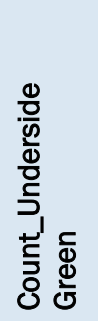 & 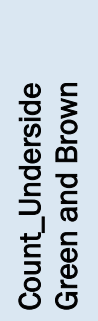 & 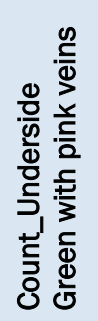 & 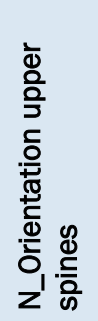 & 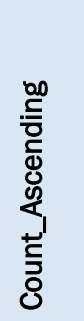 & 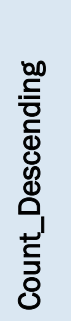 & 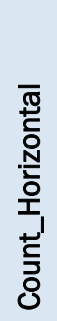 \\
\hline $1 \mathrm{WP}-\mathrm{VA}$ & 12 & 0 & 3 & 9 & 12 & 12 & 0 & 0 & 0 & 12 & 12 & 0 & 0 \\
\hline 1 VCB-VA & 10 & 0 & 5 & 5 & 12 & 12 & 0 & 0 & 0 & 12 & 12 & 0 & 0 \\
\hline Group 1 & 22 & 0 & 8 & 14 & 24 & 24 & 0 & 0 & 0 & 24 & 24 & 0 & 0 \\
\hline $2 \mathrm{ML}-\mathrm{VA}$ & 5 & 0 & 3 & 2 & 12 & 12 & 0 & 0 & 0 & 12 & 12 & 0 & 0 \\
\hline Group 2 & 5 & 0 & 3 & 2 & 12 & 12 & 0 & 0 & 0 & 12 & 12 & 0 & 0 \\
\hline 3 BR-MD & 8 & 4 & 0 & 4 & 10 & 0 & 10 & 0 & 0 & nd & nd & nd & nd \\
\hline $3 \mathrm{CH}-\mathrm{RI}$ & 0 & 0 & 0 & 0 & 12 & 0 & 12 & 0 & 0 & 12 & 12 & 0 & 0 \\
\hline $3 \mathrm{CP}-\mathrm{RI}$ & 0 & nd & nd & nd & 11 & 0 & 11 & 0 & 0 & 11 & 11 & 0 & 0 \\
\hline 3 IB-NY & 0 & nd & nd & nd & 12 & 0 & 12 & 0 & 0 & 12 & 12 & 0 & 0 \\
\hline 3 SC-NY & 0 & nd & nd & nd & 12 & 0 & 12 & 0 & 0 & 12 & 12 & 0 & 0 \\
\hline 3 TP-NY & 0 & nd & nd & nd & 12 & 0 & 12 & 0 & 0 & 12 & 12 & 0 & 0 \\
\hline 3 MM-NY & 0 & nd & nd & nd & 12 & 0 & 12 & 0 & 0 & 12 & 12 & 0 & 0 \\
\hline 3 SSB-NY & 11 & 9 & 0 & 2 & 11 & 0 & 11 & 0 & 0 & 11 & 11 & 0 & 0 \\
\hline 3 RC-NY & 12 & 8 & 0 & 4 & 12 & 0 & 1 & 11 & 0 & 12 & 12 & 0 & 0 \\
\hline 3 CDL-VT & 0 & nd & nd & nd & 12 & 0 & 12 & 0 & 0 & 12 & 12 & 0 & 0 \\
\hline 3 CCD-NY & 2 & 2 & 0 & 0 & 11 & 0 & 11 & 0 & 0 & 11 & 11 & 0 & 0 \\
\hline 3 CMB-NY & 0 & nd & nd & nd & 12 & 0 & 12 & 0 & 0 & 12 & 12 & 0 & 0 \\
\hline Group 3 & 33 & 23 & 0 & 10 & 139 & 0 & 128 & 11 & 0 & 129 & 129 & 0 & 0 \\
\hline 4 TEM-J & 1 & 1 & 0 & 0 & 12 & 0 & 5 & 0 & 7 & 12 & 12 & 0 & 0 \\
\hline $4 \mathrm{KO}-\mathrm{J}$ & 1 & 1 & 0 & 0 & 12 & 0 & 11 & 1 & 0 & 12 & 11 & 1 & 0 \\
\hline Group 4 & 2 & 2 & 0 & 0 & 24 & 0 & 16 & 1 & 7 & 24 & 23 & 1 & 0 \\
\hline 5 IWA-J & 1 & 1 & 0 & 0 & 12 & 0 & 2 & 10 & 0 & 12 & 12 & 0 & 0 \\
\hline 5 ONO-J & 1 & 1 & 0 & 0 & 12 & 0 & 11 & 1 & 0 & 12 & 12 & 0 & 0 \\
\hline 5 MIK-J & 1 & 1 & 0 & 0 & 12 & 0 & 11 & 1 & 0 & nd & nd & nd & nd \\
\hline Group 5 & 3 & 3 & 0 & 0 & 36 & 0 & 24 & 12 & 0 & 24 & 24 & 0 & 0 \\
\hline 6 NAK-J & 0 & nd & nd & nd & 11 & 0 & 11 & 0 & 0 & 11 & 11 & 0 & 0 \\
\hline Group 6 & 0 & nd & nd & nd & 11 & 0 & 11 & 0 & 0 & 11 & 11 & 0 & 0 \\
\hline 7 EM-KZN & 0 & nd & nd & nd & 12 & 0 & 0 & 12 & 0 & nd & nd & nd & nd \\
\hline Group 7 & 0 & nd & nd & nd & 12 & 0 & 0 & 12 & 0 & nd & nd & nd & nd \\
\hline
\end{tabular}




\begin{tabular}{|c|c|c|c|c|c|c|c|c|c|}
\hline 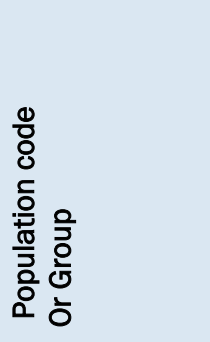 & 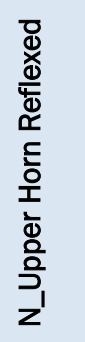 & 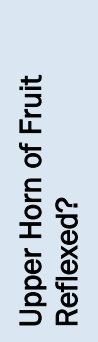 & 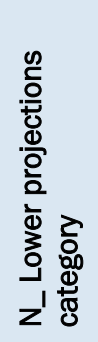 & 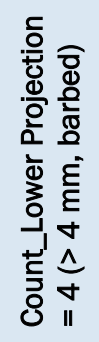 & 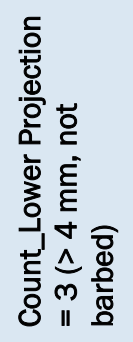 & 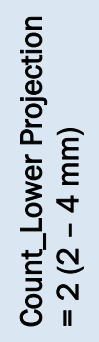 & 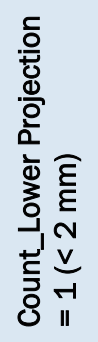 & 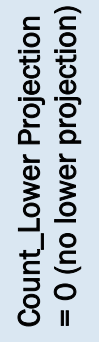 & 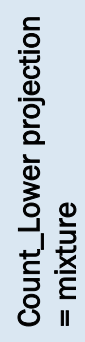 \\
\hline $1 \mathrm{WP}-\mathrm{VA}$ & 12 & 0 & 12 & 0 & 0 & 12 & 0 & 0 & 0 \\
\hline 1 VCB-VA & 12 & 0 & 12 & 0 & 0 & 10 & 0 & 0 & 2 \\
\hline Group 1 & 24 & 0 & 24 & 0 & 0 & 22 & 0 & 0 & 2 \\
\hline $2 \mathrm{ML}-\mathrm{VA}$ & 12 & 0 & 12 & 0 & 5 & 6 & 0 & 0 & 0 \\
\hline Group 2 & 12 & 0 & 12 & 0 & 5 & 6 & 0 & 0 & 0 \\
\hline 3 BR-MD & nd & nd & nd & nd & nd & nd & nd & nd & nd \\
\hline $3 \mathrm{CH}-\mathrm{RI}$ & 12 & 0 & 12 & 7 & 5 & 0 & 0 & 0 & 0 \\
\hline $3 \mathrm{CP}-\mathrm{RI}$ & 11 & 0 & 11 & 11 & 0 & 0 & 0 & 0 & 0 \\
\hline 3 IB-NY & 12 & 0 & 12 & 12 & 0 & 0 & 0 & 0 & 0 \\
\hline 3 SC-NY & 12 & 0 & 12 & 10 & 1 & 0 & 0 & 0 & 1 \\
\hline 3 TP-NY & 12 & 0 & 12 & 12 & 0 & 0 & 0 & 0 & 0 \\
\hline 3 MM-NY & 12 & 0 & 12 & 12 & 0 & 0 & 0 & 0 & 0 \\
\hline 3 SSB-NY & 11 & 0 & 11 & 11 & 0 & 0 & 0 & 0 & 0 \\
\hline 3 RC-NY & 12 & 0 & 12 & 11 & 1 & 0 & 0 & 0 & 0 \\
\hline $3 \mathrm{CDL}-\mathrm{VT}$ & 12 & 0 & 12 & 10 & 0 & 0 & 0 & 0 & 2 \\
\hline 3 CCD-NY & 11 & 0 & 11 & 10 & 0 & 0 & 0 & 0 & 1 \\
\hline 3 CMB-NY & 12 & 0 & 12 & 12 & 0 & 0 & 0 & 0 & 0 \\
\hline Group 3 & 129 & 0 & 129 & 118 & 7 & 0 & 0 & 0 & 4 \\
\hline 4 TEM-J & 12 & 0 & 12 & 9 & 1 & 1 & 1 & 0 & 0 \\
\hline 4 KO-J & 12 & 0 & 12 & 4 & 1 & 7 & 0 & 0 & 0 \\
\hline Group 4 & 24 & 0 & 24 & 13 & 2 & 8 & 1 & 0 & 0 \\
\hline 5 IWA-J & 12 & 0 & 12 & 0 & 0 & 0 & 12 & 0 & 0 \\
\hline 5 ONO-J & 12 & 0 & 12 & 2 & 0 & 1 & 9 & 0 & 0 \\
\hline 5 MIK-J & nd & nd & nd & nd & nd & nd & nd & nd & nd \\
\hline Group 5 & 24 & 0 & 24 & 2 & 0 & 1 & 21 & 0 & 0 \\
\hline 6 NAK-J & 11 & 0 & 11 & 0 & 0 & 11 & 0 & 0 & 0 \\
\hline Group 6 Totals & 11 & 0 & 11 & 0 & 0 & 11 & 0 & 0 & 0 \\
\hline 7 EM-KZN & nd & nd & nd & nd & nd & nd & nd & nd & nd \\
\hline Group 7 & nd & nd & nd & nd & nd & nd & nd & $n d$ & $n d$ \\
\hline
\end{tabular}




\begin{tabular}{|c|c|c|c|c|c|c|c|c|c|}
\hline 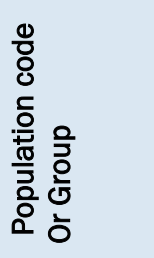 & 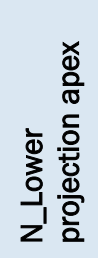 & 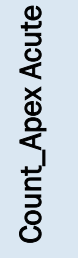 & 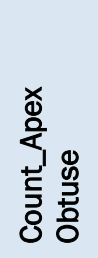 & 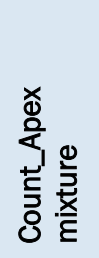 & 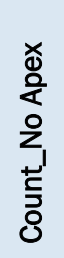 & 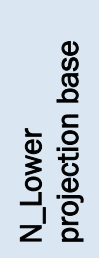 & 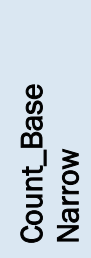 & 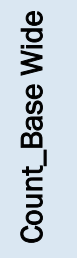 & 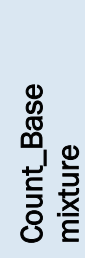 \\
\hline 1 WP-VA & 12 & 0 & 12 & 0 & 0 & 12 & 0 & 12 & 0 \\
\hline $1 \mathrm{VCB}-\mathrm{VA}$ & 12 & 0 & 10 & 2 & 0 & 12 & 0 & 12 & 0 \\
\hline Group 1 & 24 & 0 & 22 & 2 & 0 & 24 & 0 & 24 & 0 \\
\hline $2 \mathrm{ML}-\mathrm{VA}$ & 12 & 0 & 11 & 1 & 0 & 12 & 1 & 11 & 0 \\
\hline Group 2 & 12 & 0 & 11 & 1 & 0 & 12 & 1 & 11 & 0 \\
\hline 3 BR-MD & nd & nd & nd & nd & nd & nd & nd & nd & nd \\
\hline $3 \mathrm{CH}-\mathrm{RI}$ & 12 & 11 & 0 & 1 & 0 & 12 & 0 & 12 & 0 \\
\hline 3 CP-RI & 11 & 11 & 0 & 0 & 0 & 11 & 0 & 11 & 0 \\
\hline 3 IB-NY & 12 & 12 & 0 & 0 & 0 & 12 & 0 & 12 & 0 \\
\hline 3 SC-NY & 12 & 10 & 1 & 1 & 0 & 12 & 0 & 12 & 0 \\
\hline 3 TP-NY & 12 & 12 & 0 & 0 & 0 & 12 & 0 & 12 & 0 \\
\hline 3 MM-NY & 12 & 12 & 0 & 0 & 0 & 12 & 0 & 12 & 0 \\
\hline 3 SSB-NY & 11 & 11 & 0 & 0 & 0 & 11 & 0 & 11 & 0 \\
\hline 3 RC-NY & 12 & 12 & 0 & 0 & 0 & 12 & 0 & 12 & 0 \\
\hline 3 CDL-VT & 12 & 10 & 0 & 2 & 0 & 12 & 0 & 12 & 0 \\
\hline 3 CCD-NY & 11 & 10 & 0 & 1 & 0 & 11 & 0 & 11 & 0 \\
\hline 3 CMB-NY & 12 & 12 & 0 & 0 & 0 & 12 & 0 & 12 & 0 \\
\hline Group 3 & 129 & 123 & 1 & 5 & 0 & 129 & 0 & 129 & 0 \\
\hline 4 TEM-J & 12 & 9 & 3 & 0 & 0 & 12 & 0 & 12 & 0 \\
\hline 4 KO-J & 12 & 4 & 8 & 0 & 0 & 12 & 0 & 12 & 0 \\
\hline Group 4 & 24 & 13 & 11 & 0 & 0 & 24 & 0 & 24 & 0 \\
\hline 5 IWA-J & 12 & 1 & 11 & 0 & 0 & 12 & 0 & 12 & 0 \\
\hline 5 ONO-J & 12 & 2 & 10 & 0 & 0 & 12 & 1 & 11 & 0 \\
\hline 5 MIK-J & nd & nd & nd & nd & nd & nd & nd & nd & nd \\
\hline Group 5 & 24 & 3 & 21 & 0 & 0 & 24 & 1 & 23 & 0 \\
\hline 6 NAK-J & 11 & 11 & 0 & 0 & 0 & 11 & 0 & 11 & 0 \\
\hline Group 6 & 11 & 11 & 0 & 0 & 0 & 11 & 0 & 11 & 0 \\
\hline 7 EM-KZN & nd & nd & nd & nd & nd & nd & nd & nd & nd \\
\hline Group 7 & nd & nd & nd & nd & nd & nd & nd & nd & nd \\
\hline
\end{tabular}




\begin{tabular}{|c|c|c|c|c|c|c|c|}
\hline 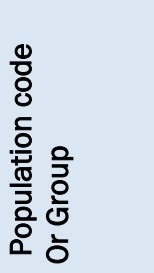 & 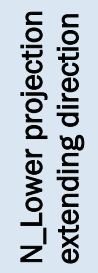 & 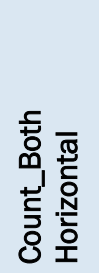 & 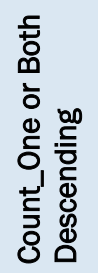 & 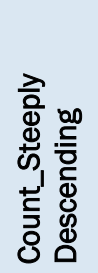 & 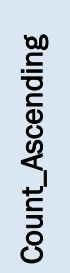 & 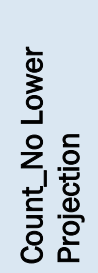 & 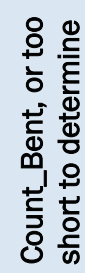 \\
\hline $1 \mathrm{WP}-\mathrm{VA}$ & 12 & 12 & 0 & 0 & 0 & 0 & 0 \\
\hline 1 VCB-VA & 12 & 9 & 3 & 0 & 0 & 0 & 0 \\
\hline Group 1 & 24 & 21 & 3 & 0 & 0 & 0 & 0 \\
\hline $2 \mathrm{ML}-\mathrm{VA}$ & 12 & 10 & 2 & 0 & 0 & 0 & 0 \\
\hline Group 2 & 12 & 10 & 2 & 0 & 0 & 0 & 0 \\
\hline 3 BR-MD & nd & nd & nd & nd & nd & nd & nd \\
\hline $3 \mathrm{CH}-\mathrm{RI}$ & 12 & 9 & 1 & 0 & 2 & 0 & 0 \\
\hline 3 CP-RI & 11 & 3 & 5 & 1 & 2 & 0 & 0 \\
\hline 3 IB-NY & 12 & 4 & 3 & 0 & 2 & 0 & 3 \\
\hline 3 SC-NY & 12 & 8 & 0 & 0 & 4 & 0 & 0 \\
\hline 3 TP-NY & 12 & 4 & 6 & 0 & 2 & 0 & 0 \\
\hline 3 MM-NY & 12 & 5 & 4 & 0 & 3 & 0 & 0 \\
\hline 3 SSB-NY & 11 & 3 & 6 & 0 & 2 & 0 & 0 \\
\hline 3 RC-NY & 12 & 5 & 5 & 0 & 2 & 0 & 0 \\
\hline 3 CDL-VT & 12 & 5 & 1 & 0 & 5 & 0 & 1 \\
\hline 3 CCD-NY & 11 & 8 & 2 & 0 & 1 & 0 & 0 \\
\hline 3 CMB-NY & 12 & 4 & 4 & 0 & 3 & 0 & 1 \\
\hline Group 3 & 129 & 58 & 37 & 1 & 28 & 0 & 5 \\
\hline 4 TEM-J & 12 & 7 & 5 & 0 & 0 & 0 & 0 \\
\hline 4 KO-J & 12 & 6 & 6 & 0 & 0 & 0 & 0 \\
\hline Group 4 & 24 & 13 & 11 & 0 & 0 & 0 & 0 \\
\hline 5 IWA-J & 12 & 2 & 0 & 0 & 0 & 0 & 10 \\
\hline 5 ONO-J & 12 & 8 & 3 & 0 & 0 & 0 & 1 \\
\hline 5 MIK-J & nd & nd & nd & nd & nd & nd & nd \\
\hline Group 5 & 24 & 10 & 3 & 0 & 0 & 0 & 11 \\
\hline 6 NAK-J & 11 & 0 & 0 & 11 & 0 & 0 & 0 \\
\hline Group 6 & 11 & 0 & 0 & 11 & 0 & 0 & 0 \\
\hline 7 EM-KZN & nd & nd & nd & nd & nd & nd & nd \\
\hline Group 7 & nd & nd & nd & nd & nd & nd & nd \\
\hline
\end{tabular}




\begin{tabular}{|c|c|c|c|c|c|c|c|c|c|c|c|c|c|}
\hline 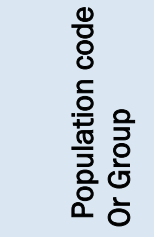 & 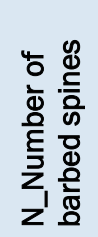 & $\begin{array}{l}\mathscr{8} \\
\stackrel{5}{\circ} \\
\text { के } \\
\nabla_{1} \\
\vec{J}^{\prime} \\
\overline{0}\end{array}$ & 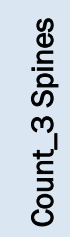 & 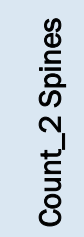 & 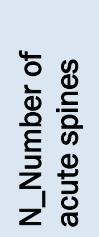 & 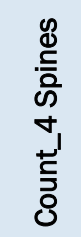 & 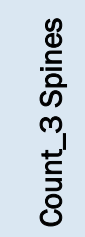 & 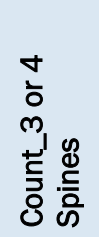 & 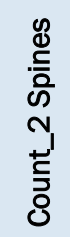 & 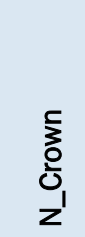 & 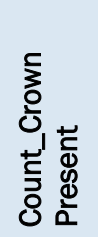 & 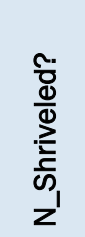 & 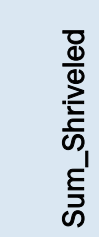 \\
\hline 1 WP-VA & 12 & 0 & 0 & 12 & 12 & 0 & 0 & 0 & 12 & 12 & 0 & 12 & 0 \\
\hline 1 VCB-VA & 12 & 0 & 2 & 10 & 12 & 0 & 2 & 0 & 10 & 12 & 0 & 12 & 3 \\
\hline Group 1 & 24 & 0 & 2 & 22 & 24 & 0 & 2 & 0 & 22 & 24 & 0 & 24 & 3 \\
\hline $2 \mathrm{ML}-\mathrm{VA}$ & 12 & 0 & 0 & 12 & 12 & 0 & 0 & 1 & 11 & 12 & 0 & 12 & 0 \\
\hline Group 2 & 12 & 0 & 0 & 12 & 12 & 0 & 0 & 1 & 11 & 12 & 0 & 12 & 0 \\
\hline 3 BR-MD & nd & nd & nd & nd & nd & nd & nd & nd & nd & nd & nd & nd & nd \\
\hline $3 \mathrm{CH}-\mathrm{RI}$ & 12 & 7 & 0 & 5 & 12 & 11 & 0 & 1 & 0 & 12 & 12 & 12 & 0 \\
\hline 3 CP-RI & 11 & 11 & 0 & 0 & 11 & 11 & 0 & 0 & 0 & 11 & 11 & 11 & 0 \\
\hline 3 IB-NY & 12 & 12 & 0 & 0 & 12 & 12 & 0 & 0 & 0 & 12 & 12 & 12 & 0 \\
\hline 3 SC-NY & 12 & 10 & 1 & 1 & 12 & 10 & 1 & 0 & 1 & 12 & 11 & 12 & 0 \\
\hline 3 TP-NY & 12 & 12 & 0 & 0 & 12 & 12 & 0 & 0 & 0 & 12 & 12 & 12 & 0 \\
\hline 3 MM-NY & 12 & 12 & 0 & 0 & 12 & 12 & 0 & 0 & 0 & 12 & 8 & 12 & 0 \\
\hline 3 SSB-NY & 11 & 11 & 0 & 0 & 11 & 11 & 0 & 0 & 0 & 11 & 11 & 11 & 0 \\
\hline 3 RC-NY & 12 & 11 & 0 & 1 & 12 & 12 & 0 & 0 & 0 & 12 & 11 & 12 & 0 \\
\hline 3 CDL-VT & 12 & 10 & 2 & 0 & 12 & 10 & 2 & 0 & 0 & 12 & 12 & 12 & 0 \\
\hline 3 CCD-NY & 11 & 10 & 0 & 1 & 11 & 10 & 1 & 0 & 0 & 11 & 11 & 11 & 0 \\
\hline 3 CMB-NY & 12 & 12 & 0 & 0 & 12 & 12 & 0 & 0 & 0 & 12 & 12 & 12 & 1 \\
\hline Group 3 & 129 & 118 & 3 & 8 & 129 & 123 & 4 & 1 & 1 & 129 & 123 & 129 & 1 \\
\hline 4 TEM-J & 12 & 9 & 0 & 3 & 12 & 9 & 0 & 0 & 3 & 12 & 12 & 12 & 0 \\
\hline 4 KO-J & 12 & 4 & 0 & 8 & 12 & 4 & 0 & 0 & 8 & 12 & 12 & 12 & 0 \\
\hline Group 4 & 24 & 13 & 0 & 11 & 24 & 13 & 0 & 0 & 11 & 24 & 24 & 24 & 0 \\
\hline 5 IWA-J & 12 & 0 & 0 & 12 & 12 & 1 & 0 & 0 & 11 & 12 & 12 & 12 & 0 \\
\hline 5 ONO-J & 12 & 2 & 0 & 10 & 12 & 2 & 0 & 0 & 10 & 12 & 12 & 12 & 1 \\
\hline 5 MIK-J & nd & nd & nd & nd & nd & nd & nd & nd & nd & nd & nd & nd & nd \\
\hline Group 5 & 24 & 2 & 0 & 22 & 24 & 3 & 0 & 0 & 21 & 24 & 24 & 24 & 1 \\
\hline 6 NAK-J & 11 & 11 & 0 & 0 & 11 & 11 & 0 & 0 & 0 & 11 & 0 & 11 & 0 \\
\hline Group 6 & 11 & 11 & 0 & 0 & 11 & 11 & 0 & 0 & 0 & 11 & 0 & 11 & 0 \\
\hline 7 EM-KZN & nd & nd & nd & nd & nd & nd & nd & nd & nd & nd & nd & nd & nd \\
\hline Group 7 & nd & nd & nd & nd & nd & nd & nd & nd & nd & nd & nd & nd & nd \\
\hline
\end{tabular}


Appendix Table A-2c. Sample size (N), average, and standard error (SE) of selected morphological parameters by population and genetic group ( $\mathrm{nd}=$ no data).

\begin{tabular}{|c|c|c|c|c|c|c|c|c|c|c|c|c|}
\hline 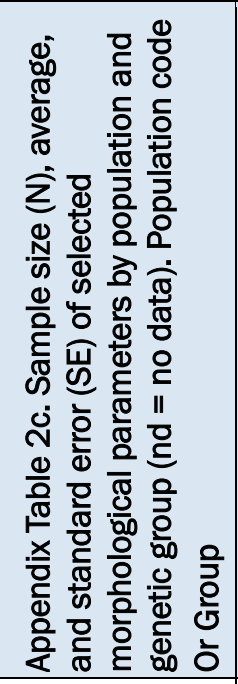 & 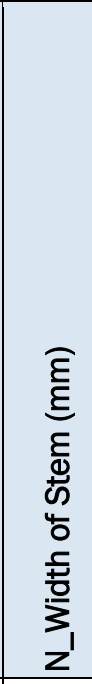 & 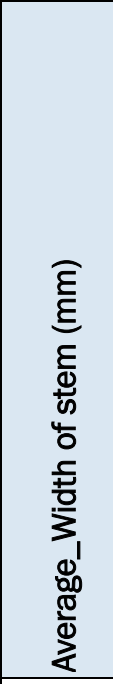 & 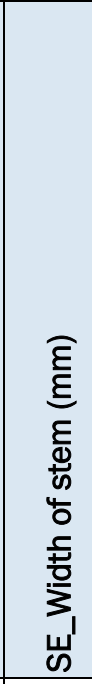 & 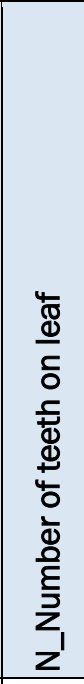 & 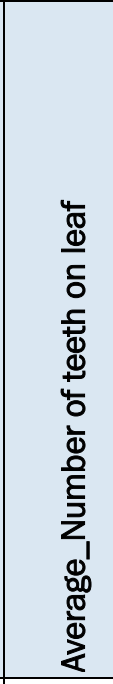 & 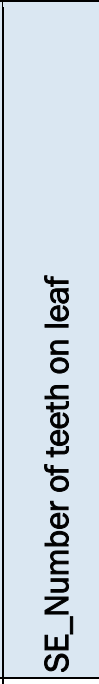 & 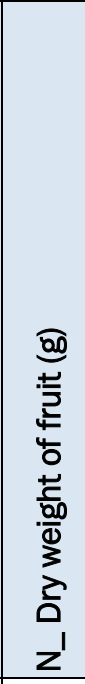 & 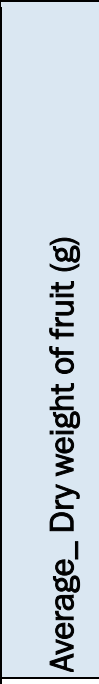 & 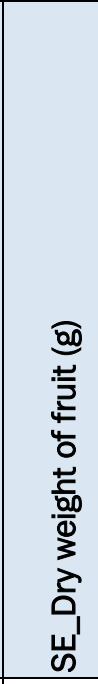 & 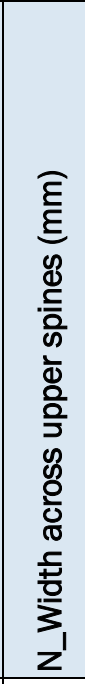 & 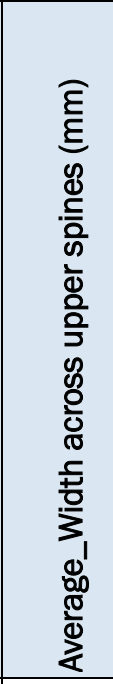 & 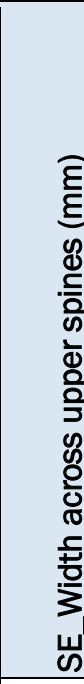 \\
\hline 1 WP-VA & 12 & 5.00 & 0.30 & 12 & 21.00 & 0.25 & 12 & 1.19 & 0.10 & 12 & 34.49 & 0.49 \\
\hline 1 VCB-VA & 12 & 4.88 & 0.20 & 12 & 23.58 & 0.85 & 12 & 0.48 & 0.03 & 12 & 30.86 & 1.70 \\
\hline Group 1 & 24 & 4.94 & 0.17 & 24 & 22.29 & 0.51 & 24 & 0.84 & 0.09 & 24 & 32.68 & 0.94 \\
\hline $2 \mathrm{ML}-\mathrm{VA}$ & 12 & 5.21 & 0.20 & 12 & 24.83 & 0.41 & 12 & 0.60 & 0.42 & 12 & 35.64 & 0.72 \\
\hline Group 2 & 12 & 5.21 & 0.20 & 12 & 24.83 & 0.41 & 12 & 0.60 & 0.06 & 12 & 35.64 & 0.72 \\
\hline $3 \mathrm{CH}-\mathrm{RI}$ & 0 & nd & nd & 12 & 15.33 & 0.47 & 12 & 1.97 & 0.13 & 12 & 40.90 & 1.16 \\
\hline 3 CP-RI & 0 & nd & nd & 10 & 20.90 & 0.67 & 11 & 1.19 & 0.11 & 11 & 36.02 & 0.89 \\
\hline 3 IB-NY & 12 & 20.21 & 0.33 & 11 & 18.18 & 0.69 & 12 & 1.34 & 0.22 & 12 & 36.30 & 1.28 \\
\hline 3 SC-NY & 12 & 15.50 & 0.74 & 7 & 40.43 & 1.56 & 12 & 1.71 & 0.22 & 12 & 36.64 & 1.32 \\
\hline 3 TP-NY & 12 & 15.75 & 0.83 & 12 & 15.33 & 0.66 & 12 & 1.65 & 0.23 & 12 & 37.83 & 1.09 \\
\hline 3 MM-NY & 12 & 13.00 & 0.85 & 12 & 19.67 & 0.38 & 12 & 2.12 & 0.16 & 12 & 37.13 & 1.34 \\
\hline 3 SSB-NY & 11 & 10.27 & 0.73 & 11 & 20.09 & 0.31 & 11 & 2.56 & 0.18 & 11 & 46.14 & 1.07 \\
\hline 3 RC-NY & 12 & 11.83 & 1.34 & 12 & 17.83 & 0.52 & 12 & 2.00 & 0.25 & 12 & 38.42 & 1.18 \\
\hline 3 CDL-VT & 12 & 18.29 & 0.63 & 12 & 16.08 & 0.47 & 12 & 2.00 & 0.18 & 12 & 40.68 & 1.09 \\
\hline 3 CCD-NY & 11 & 12.50 & 1.33 & 11 & 21.91 & 0.81 & 11 & 2.19 & 0.20 & 11 & 42.59 & 0.95 \\
\hline 3 CMB-NY & 12 & 15.13 & 1.11 & 12 & 17.92 & 0.47 & 12 & 1.64 & 0.21 & 12 & 37.34 & 1.49 \\
\hline Group 3 & 106 & 14.78 & 0.42 & 122 & 18.38 & 0.26 & 129 & 1.85 & 0.07 & 129 & 39.03 & 0.43 \\
\hline 4 TEM-J & 0 & nd & nd & 12 & 28.50 & 0.95 & 12 & 2.32 & 0.20 & 12 & 56.25 & 1.47 \\
\hline 4 KO-J & 0 & nd & nd & 12 & 30.42 & 0.92 & 12 & 2.03 & 0.14 & 12 & 54.87 & 1.20 \\
\hline Group 4 & 0 & nd & nd & 24 & 29.46 & 0.68 & 24 & 2.17 & 0.12 & 24 & 55.56 & 0.94 \\
\hline 5 IWA-J & 0 & nd & nd & 12 & 27.17 & 0.80 & 12 & 1.04 & 0.09 & 12 & 39.06 & 0.95 \\
\hline 5 ONO-J & 0 & nd & nd & 12 & 25.42 & 0.81 & 12 & 0.65 & 0.11 & 12 & 30.56 & 1.16 \\
\hline
\end{tabular}




\begin{tabular}{|c|c|c|c|c|c|c|c|c|c|c|c|c|}
\hline 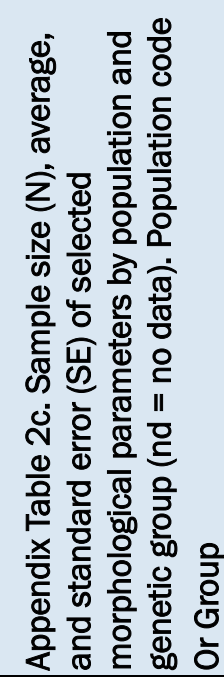 & 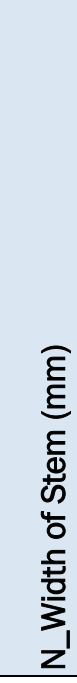 & 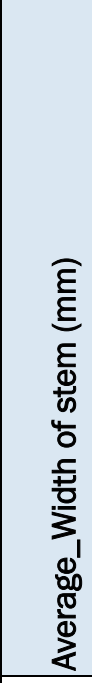 & 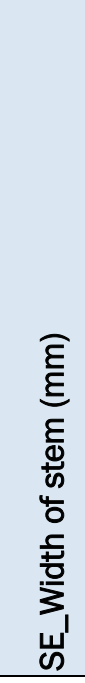 & 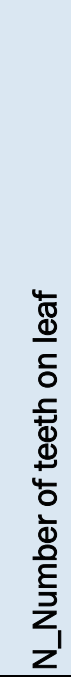 & 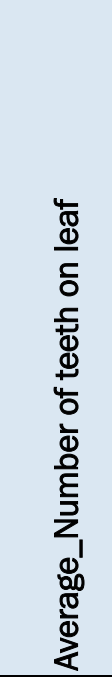 & 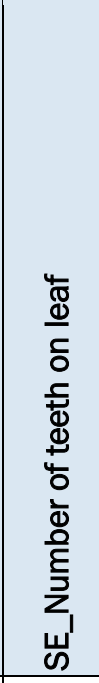 & 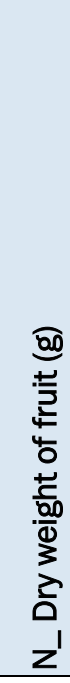 & 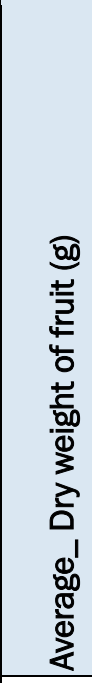 & 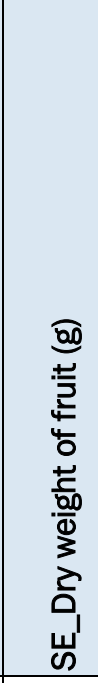 & 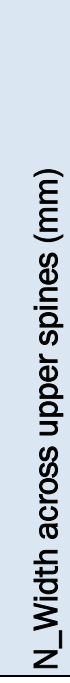 & 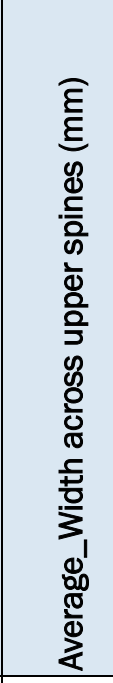 & 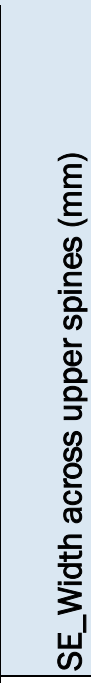 \\
\hline Group 5 & 0 & nd & nd & 24 & 26.29 & 0.59 & 24 & 0.84 & 0.08 & 24 & 34.81 & 1.15 \\
\hline 6 NAK-J & 0 & nd & nd & 11 & 11.09 & 0.59 & 11 & 0.08 & 0.00 & 11 & 17.51 & 0.80 \\
\hline Group 6 & 0 & nd & nd & 11 & 11.09 & 0.28 & 11 & 0.08 & 0.00 & 11 & 17.51 & 0.80 \\
\hline 7 EM-KZN & 12 & 3.50 & 0.31 & 12 & 16.83 & 0.83 & nd & nd & nd & nd & nd & nd \\
\hline Group 7 & 12 & 3.50 & 0.31 & 12 & 16.83 & 0.83 & nd & nd & nd & nd & nd & nd \\
\hline
\end{tabular}

Appendix Table A-2c - continued. Sample size (N), average, and standard error (SE) of selected morphological parameters by population and genetic group ( $\mathrm{nd}=$ no data).

\begin{tabular}{|c|c|c|c|c|c|c|c|c|c|}
\hline 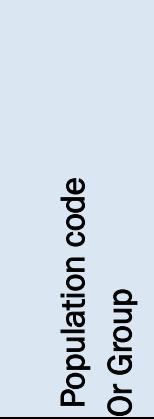 & 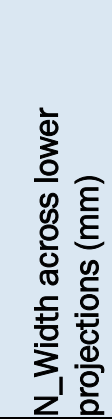 & 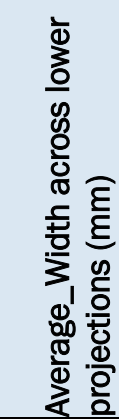 & 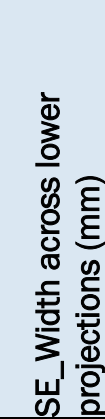 & 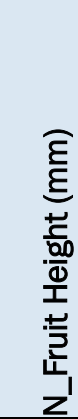 & 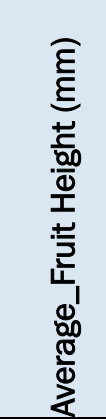 & 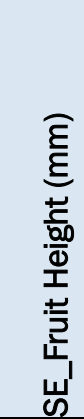 & 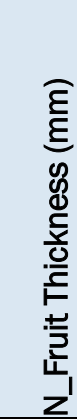 & 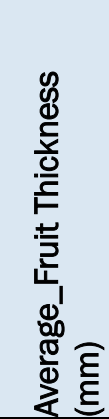 & 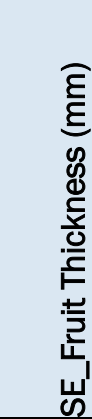 \\
\hline 1 WP-VA & 12 & 19.64 & 0.63 & 12 & 17.20 & 0.51 & 12 & 10.64 & 0.23 \\
\hline 1 VCB-VA & 12 & 18.69 & 0.70 & 12 & 13.25 & 0.38 & 12 & 8.58 & 0.36 \\
\hline Group 1 & 24 & 19.16 & 0.47 & 24 & 15.22 & 0.52 & 24 & 9.61 & 0.30 \\
\hline $2 \mathrm{ML}-\mathrm{VA}$ & 12 & 16.20 & 0.81 & 12 & 14.11 & 0.49 & 12 & 10.48 & 0.75 \\
\hline Group 2 & 12 & 16.20 & 0.81 & 12 & 14.11 & 0.49 & 12 & 10.48 & 0.75 \\
\hline $3 \mathrm{CH}-\mathrm{RI}$ & 12 & 29.00 & 1.31 & 12 & 18.78 & 0.80 & 12 & 11.78 & 0.22 \\
\hline $3 \mathrm{CP}-\mathrm{RI}$ & 11 & 29.24 & 1.10 & 11 & 19.58 & 0.30 & 11 & 12.01 & 0.33 \\
\hline 3 IB-NY & 12 & 29.95 & 1.10 & 12 & 18.79 & 1.37 & 12 & 11.42 & 0.45 \\
\hline 3 SC-NY & 12 & 30.09 & 1.41 & 12 & 19.19 & 0.70 & 12 & 12.47 & 0.45 \\
\hline 3 TP-NY & 12 & 29.38 & 0.94 & 12 & 18.59 & 0.56 & 12 & 11.84 & 0.43 \\
\hline $3 \mathrm{MM}-\mathrm{NY}$ & 12 & 30.09 & 0.75 & 12 & 18.68 & 0.49 & 12 & 11.59 & 0.35 \\
\hline 3 SSB-NY & 11 & 38.50 & 1.00 & 11 & 23.91 & 0.62 & 11 & 12.86 & 0.54 \\
\hline
\end{tabular}




\begin{tabular}{|c|c|c|c|c|c|c|c|c|c|}
\hline 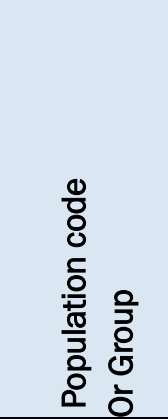 & 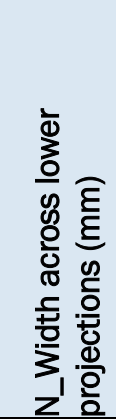 & 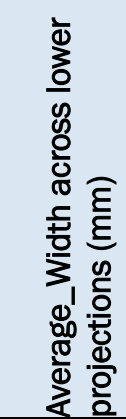 & 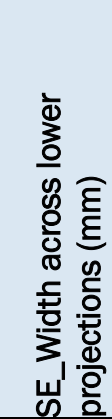 & 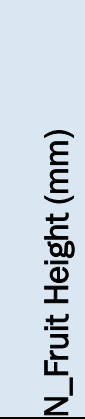 & 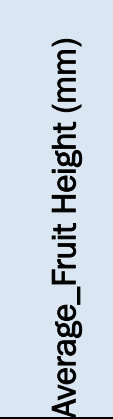 & 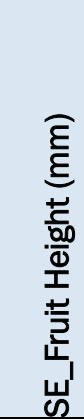 & 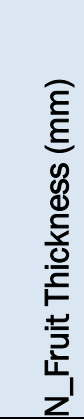 & 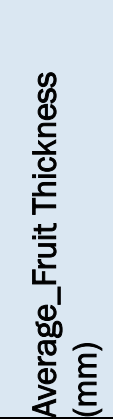 & 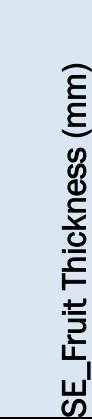 \\
\hline 3 RC-NY & 12 & 30.51 & 1.96 & 12 & 20.77 & 1.00 & 12 & 11.52 & 0.40 \\
\hline 3 CDL-VT & 12 & 30.13 & 1.45 & 12 & 20.25 & 0.62 & 12 & 11.63 & 0.32 \\
\hline 3 CCD-NY & 11 & 32.48 & 1.39 & 11 & 22.46 & 0.70 & 11 & 12.83 & 0.32 \\
\hline 3 CMB-NY & 12 & 28.99 & 1.28 & 12 & 19.28 & 0.66 & 12 & 11.33 & 0.58 \\
\hline Group 3 & 129 & 30.70 & 0.44 & 129 & 19.98 & 0.26 & 129 & 11.92 & 0.13 \\
\hline 4 TEM-J & 12 & 41.91 & 4.59 & 12 & 22.66 & 0.58 & 12 & 12.42 & 0.56 \\
\hline $4 \mathrm{KO}-\mathrm{J}$ & 12 & 29.50 & 4.48 & 12 & 20.63 & 0.56 & 12 & 13.07 & 0.52 \\
\hline Group 4 & 24 & 35.71 & 3.39 & 24 & 21.64 & 0.45 & 24 & 12.70 & 0.38 \\
\hline 5 IWA-J & 12 & 11.08 & 0.49 & 12 & 16.82 & 0.47 & 12 & 9.90 & 0.19 \\
\hline 5 ONO-J & 12 & 14.08 & 2.48 & 12 & 16.09 & 0.75 & 12 & 8.55 & 0.29 \\
\hline Group 5 & 24 & 12.58 & 1.28 & 24 & 16.45 & 0.44 & 24 & 9.23 & 0.22 \\
\hline 6 NAK-J & 11 & 4.16 & 0.11 & 11 & 8.64 & 0.24 & 11 & 3.65 & 0.12 \\
\hline Group 6 & 11 & 4.16 & 0.11 & 11 & 8.64 & 0.24 & 11 & 3.65 & 0.12 \\
\hline 7 EM-KZN & nd & nd & nd & nd & nd & nd & nd & nd & nd \\
\hline Group 7 & nd & nd & nd & nd & nd & nd & nd & nd & nd \\
\hline
\end{tabular}




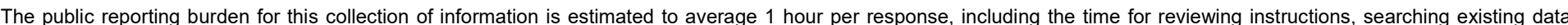

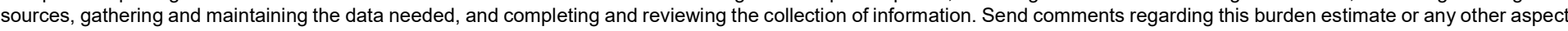

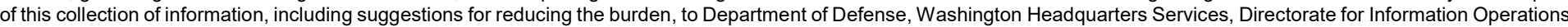

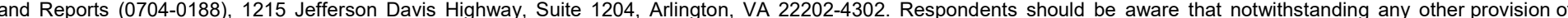
law, no person shall be subject to any penalty for failing to comply with a collection of information if it does not display a currently valid OMB control number.

PLEASE DO NOT RETURN YOUR FORM TO THE ABOVE ADDRESS.

\begin{tabular}{|l|l|l|l|l}
\hline 1. REPORT DATE & 2. REPORT TYPE & 3. DATES COVERED (FrOm - To)
\end{tabular}

\begin{tabular}{l|l} 
March 2019 & Final \\
\hline
\end{tabular}

\section{TITLE AND SUBTITLE}

Final

Genetic and Morphological Differences of Water Chestnut (Myrtales: Lythraceae: Trapa)

Populations in the Northeastern United States, Japan, and South Africa

5a. CONTRACT NUMBER

Lynde L. Dodd, Nancy Rybicki, Ryan Thum, Yasuro Kadono,

and Kadiera Ingram

5b. GRANT NUMBER

5c. PROGRAM ELEMENT NUMBER

5d. PROJECT NUMBER

5e. TASK NUMBER

5f. WORK UNIT NUMBER

33143

\section{PERFORMING ORGANIZATION NAME(S) AND ADDRESS(ES)}

U.S Army Engineer Research and Development Center

Environmental Laboratory

3909 Halls Ferry Road, Vicksburg, MS 39180-6199

8. PERFORMING ORGANIZATION REPORT NUMBER

ERDC/EL TR-19-3

9. SPONSORING/MONITORING AGENCY NAME(S) AND ADDRESS(ES)

10. SPONSOR/MONITOR'S ACRONYM(S)

Headquarters, U.S. Army Corps of Engineers

Washington, DC 20314-1000

11. SPONSOR/MONITOR'S REPORT NUMBER(S)

\section{DISTRIBUTION/AVAILABILITY STATEMENT}

Approved for public release; distribution is unlimited.

\section{SUPPLEMENTARY NOTES}

\section{ABSTRACT}

Cryptic introductions are non-native species that have been introduced outside of native ranges; these introductions are undetected because the species have morphology similar to native or other non-native species naturalized within the same region. While non-native, invasive Trapa natans has been present in the Northeastern (NE) United States (U.S.) since the late 1800s, unpublished data suggests a new introduction of Trapa has occurred in the Commonwealth of Virginia. This population was distinct: it had 2-spined fruit as opposed to the typical 4-spined fruit associated with $T$. natans. It was therefore suspected as a cryptic introduction of Trapa species.

This work aims to elucidate genetic and morphological differences of naturalized Trapa taxa (water chestnut) in the NE U.S. Comparisons of morphological characteristics and genetics were made between Trapa populations from the native regions of Eurasia and Africa versus those of the NE U.S. Results of the morphological analysis supported genetic results that 2-spine Trapa sp. and 4-spine T. natans in the U.S. were different, with the number of spines and the presence of a crown (Trapa sp. lacks a crown) as morphological taxonomic indicators.

\section{SUBJECT TERMS}

Aquatic plants, Cryptic introductions, Invasive vegetative species, Morphological analysis, Trapa natans, Water chestnut

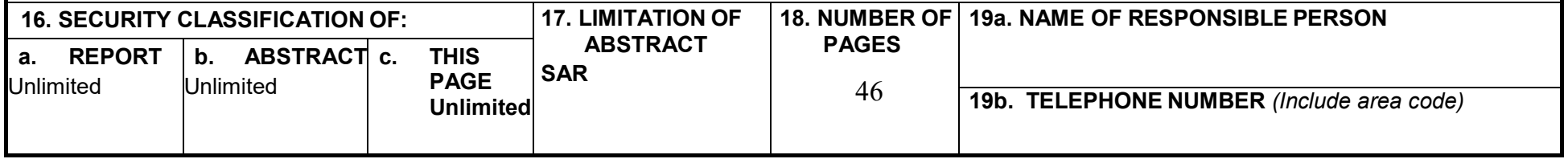

